\title{
22. LOW-TEMPERATURE HYDROTHERMAL ALTERATION OF JURASSIC OCEAN CRUST, SITE $801^{1}$
}

\author{
Jeffrey C. Alt, ${ }^{2}$ Christian France-Lanord, ${ }^{3}$ P. A. Floyd, ${ }^{4}$ Paterno Castillo, ${ }^{5}$ and Albert Galy ${ }^{3}$
}

\begin{abstract}
Low-temperature hydrothermal alteration of basement from Site 801 was studied through analyses of the mineralogy, chemistry, and oxygen isotopic compositions of the rocks. The more than 100-m section of 170-Ma basement consists of $60 \mathrm{~m}$ of tholeiitic basalt separated from the overlying $60 \mathrm{~m}$ of alkalic basalts by a $>3-\mathrm{m}$-thick Fe-Si hydrothermal deposit. Four alteration types were distinguished in the basalts: (1) saponite-type ( $\mathrm{Mg}$-smectite) rocks are generally slightly altered, exhibiting small increases in $\mathrm{H}_{2} \mathrm{O}, \delta^{18} \mathrm{O}$, and oxidation; (2) celadonite-type rocks are also slightly altered, but exhibit uptake of alkalis in addition to hydration and oxidation, reflecting somewhat greater seawater/rock ratios than the saponite type; (3) Al-saponite-type alteration resulted in oxidation, hydration, and alkali and ${ }^{18} \mathrm{O}$ uptake and losses of $\mathrm{Ca}$ and $\mathrm{Na}$ due to the breakdown of plagioclase and clinopyroxene; and (4) blue-green rocks exhibit the greatest chemical changes, including oxidation, hydration, alkali uptake, and loss of $\mathrm{Ca}, \mathrm{Na}$, and $\mathrm{Mg}$ due to the complete breakdown of plagioclase and olivine to $\mathrm{K}$-feldspar and phyllosilicates.

Saponite- and celadonite-type alteration of the tholeiite section occurred at a normal mid-ocean ridge basalt spreading center at temperatures $<20^{\circ} \mathrm{C}$. Near- or off-axis intrusion of an alkali basalt magma at depth reinitiated hydrothermal circulation, and the $\mathrm{Fe}$-Si hydrothermal deposit formed from cool $\left(<60^{\circ} \mathrm{C}\right)$ distal hydrothermal fluids. Focusing of fluid flow in the rocks immediately underlying the deposit resulted in the extensive alteration of the blue-green rocks at similar temperatures. Al-saponite alteration of the subsequent alkali basalts overlying the deposit occurred at relatively high water/rock ratios as part of the same low-temperature circulation system that formed the hydrothermal deposit. Abundant calcite formed in the rocks during progressive "aging" of the crust during its long history away from the spreading center.
\end{abstract}

\section{INTRODUCTION}

Drilling at Site 801 on Leg 129 of the Ocean Drilling Program (ODP) penetrated more than $100 \mathrm{~m}$ into Jurassic oceanic basement in the western Pacific. This is the oldest in-situ oceanic basement ever drilled and presents an excellent opportunity to study processes associated with the formation and evolution of ancient ocean crust. The cores contain a section of tholeiitic basalts separated from overlying alkali basalts by a $>3$-m-thick siliceous iron-oxyhydroxide hydrothermal deposit.

This paper presents the results of a study of the alteration of basement rocks recovered from Site 801. Data on the secondary mineralogy, whole-rock chemical compositions, and oxygen and carbon isotope ratios are presented in order to constrain the alteration conditions and processes and to evaluate chemical and isotopic exchange between seawater and the crust. One of the questions of interest is whether such old crust has undergone progressive "aging," exhibiting mineralogical and chemical changes related to its long history of seafloor spreading, and whether it is more altered than much younger crust closer to the spreading center.

\section{Site 801}

Site 801 is located in the central Pigafetta Basin in the western Pacific, at a water depth of $5673.8 \mathrm{~m}$ (Fig. 1). The oldest sediment at the base of the 461.6-m sedimentary section is Callovian-Bathonian in age, giving an age of about $165 \mathrm{Ma}$ for underlying basement (see

'Larson, R. L., Lancelot, Y., et al., 1992. Proc. ODP, Sci. Results, 129: College Station, TX (Ocean Drilling Program)

${ }^{2}$ Department of Geological Sciences, The University of Michigan, 1006 C.C. Little Building, Ann Arbor, MI 48109-1063, U.S.A.

${ }^{3}$ Centre de Recherches Petrographiques et Geochimiques (CRPG), B.P. 20, 54501 Vandoeuvre Cedex, France.

${ }^{4}$ Department of Geology, University of Keele, Keele, Staffordshire, 5T5 5BG, United Kingdom.

${ }^{3}$ Geological Research Division, Scripps Institution of Oceanography, University of California at San Diego, La Jolla, CA 92093, U.S.A. also Pringle, this volume). Holes $801 \mathrm{~A}$ and $801 \mathrm{~B}$ penetrated the sediment section, and Hole $801 \mathrm{~B}$ extended $48.9 \mathrm{~m}$ into basement with $31 \%$ recovery. In Hole $801 \mathrm{C}$, located only $20 \mathrm{~m}$ from Hole $801 \mathrm{~B}$, we penetrated $100.6 \mathrm{~m}$ into basement with $60.2 \%$ recovery. Basement in both holes consists of pillow basalts, thin flows, and a few thin intrusive units, plus a siliceous hydrothermal deposit in Hole 801C, and is described in detail elsewhere (Lancelot, Larson, et al., 1990). An intrusive unit and its host rock that occurs at approximately the same depth below seafloor in both holes allowed correlation between the closely spaced holes (Lancelot, Larson, et al., 1990). The basement section thus totals $132.7 \mathrm{~m}$, with $16.8 \mathrm{~m}$ of overlap between the two cores. On the basis of major and trace element geochemistry, the basement can be divided into two sections separated by the hydrothermal deposit at 525 meters below seafloor (mbsf) in Hole 801C (Fig. 2). The lower section is tholeiitic normal mid-ocean ridge basalt (N-MORB) formed at an active Jurassic spreading center, whereas the upper section consists of alkalic ocean-island-type basalts formed during subsequent near- or off-axis volcanism (Floyd and Castillo, this volume). Both primitive and evolved suites occur within each basement section (Floyd and Castillo, this volume).

\section{METHODS}

Secondary minerals were identified by optical examination of polished thin sections and with compositional data from electron microprobe analyses. The latter were performed with an automated Cameca CAMEBAX instrument at the University of Michigan, using $12-\mathrm{kV}$ accelerating voltage, $10-\mathrm{nA}$ current, and rastering the beam over a square area, $6 \mu \mathrm{m}$ on a side. Analytical techniques and results for whole-rock chemical analyses are given in the "Summary of Geochemical Data" chapter (Castillo et al., this volume). Oxygen and carbon isotopic extractions and analyses were performed at the CRPG in Vandoeuvre, France. Oxygen was extracted from splits of wholerock powders for oxygen isotopic analysis using the $\mathrm{BrF}_{5}$ method of Clayton and Mayeda (1963). $\mathrm{CO}_{2}$ was extracted from carbonates in whole rocks and from veins for isotopic analysis by dissolution in phosphoric acid at $25^{\circ} \mathrm{C}$ for 7 days. Yields for whole-rock extractions 


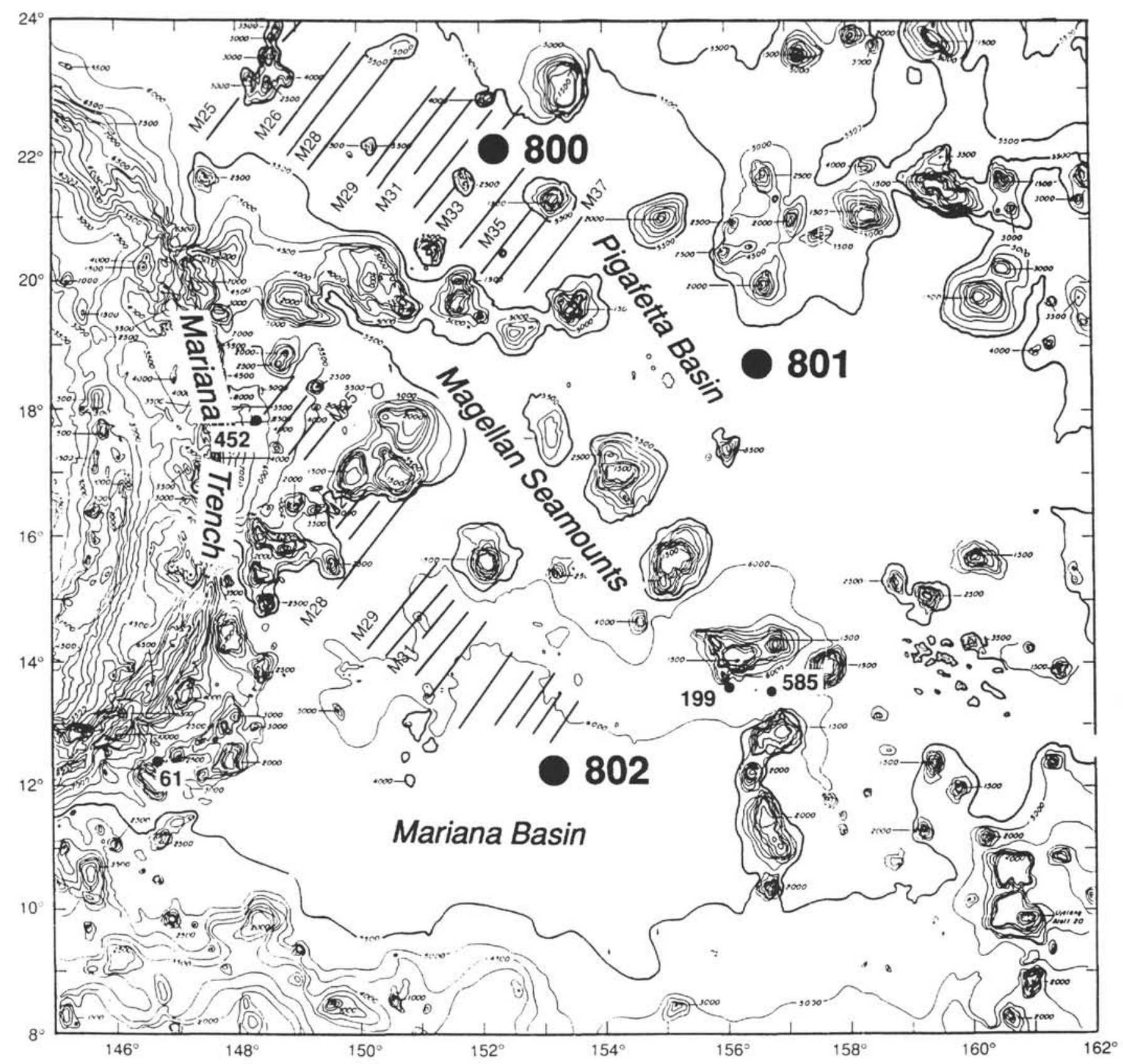

Figure 1. Location of Leg 129 Sites 800-802 in the western Pacific. Bedrock isochrons determined from magnetic anomaly lineations (from Lancelot, Larson, et al., 1990). Bathymetry in meters.

are somewhat lower than total $\mathrm{CO}_{2}$ because of the presence of siderite. One sample was extracted at $150^{\circ} \mathrm{C}$ in order to dissolve siderite. Results are reported as standard $\delta$ notation relative to Pee-Dee belemnite (PDB) and standard mean ocean water (SMOW) (Craig, 1961).

\section{RESULTS}

\section{Alteration Types and Distribution}

Four different alteration types have been recognized in Site 801 samples on the basis of their secondary mineral assemblages. Three of these types are based on the dominant clay mineral present (saponite, celadonite, or $\mathrm{Al}$-saponite), and the fourth by the blue-green color of the rocks, characteristic mineral assemblage (montmorillonite-beidellite, glauconite, celadonite, and $\mathrm{K}$-feldspar), and restricted distribution in the core. These alteration types are described in the following sections, along with their distribution in the cores.

\section{Saponite-Type Alteration}

The most abundant alteration type is characterized by the presence of saponite (trioctahedral Mg-smectite) and pyrite (Fig. 3A). The saponite in Site 801 rocks is Fe-bearing, with $\mathrm{Fe} / \mathrm{Fe}+\mathrm{Mg}=0.2-0.6$ (Fig. 4 and Table 1). Al contents are low, $<0.5$ atoms per formula $\mathrm{O}_{10}(\mathrm{OH})_{2}$, and $\mathrm{Ca}$ is the dominant interlayer cation.

These rocks are generally dark gray in color, but range to lighter gray and slightly brownish, and occur throughout most of the tholeiitic section below the hydrothermal deposit (from 534 to 591 mbsf, the bottom of the core). The rocks are mostly $10 \%-20 \%$ altered, but 

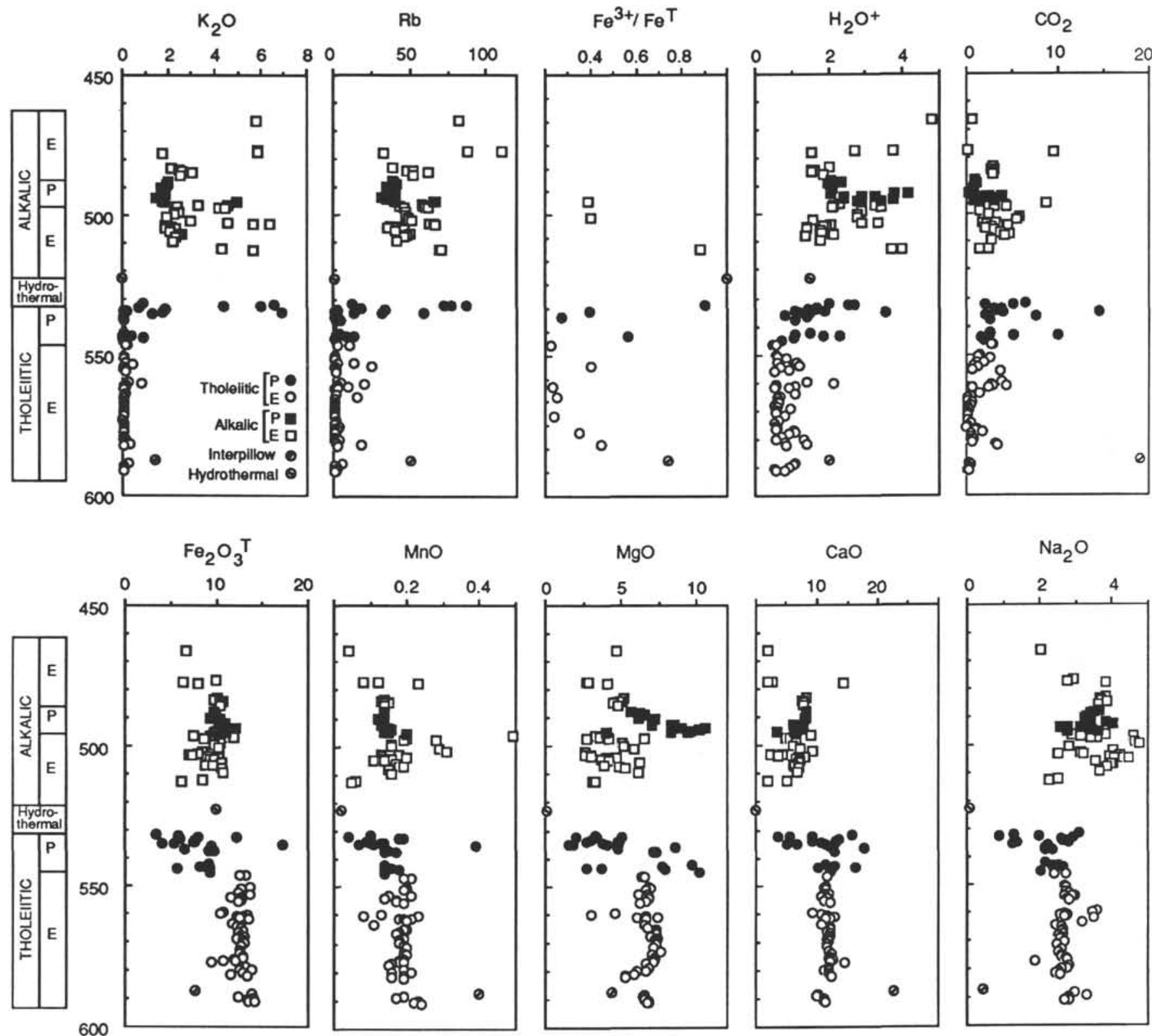

Figure 2. Lithostratigraphy and chemical compositions of basalts vs. depth for Site 801 basement. $\mathrm{E}=$ evolved compositions, $\mathrm{P}=$ primitive compositions (after Floyd, this volume).

range up to $40 \%$ altered. Olivine is totally replaced by saponite, calcite, and small amounts of pyrite. Plagioclase and clinopyroxene are generally unaltered, but both are locally slightly $(5 \%)$ replaced by saponite. Igneous titanomagnetite is only slightly altered, exhibiting shrinkage cracks due to oxidation (Petersen et al., 1979). Pyrite is commonly disseminated in the rocks, replacing silicates and igneous sulfide globules, and interstitial to silicates. Vesicles and pore space are filled with saponite, calcite, and pyrite, generally with calcite formed as the last phase at the center of the vugs. In more extensively altered samples, fine-grained interstitial material is also apparently replaced by saponite.

The alkali basalts from the upper portion of the hole that were affected by saponitic alteration are more extensively altered than the tholeiites $(30 \%-80 \%$ vs. about $10 \%-20 \%$, respectively). Plagioclase and clinopyroxene are generally unaltered in the tholeiites, whereas they are respectively $10 \%-30 \%$ and $20 \%-90 \%$ replaced by saponite and calcite in the alkalic basalts.
Veins in rocks containing the saponite assemblage consist most commonly of saponite \pm pyrite \pm calcite and range from tens of micrometers to about $1 \mathrm{~mm}$ wide. In some samples pyrite partly replaces marcasite in these veins. Several stages of calcite precipitation have occurred in many cases, with the multiple reopening and filling of fractures until originally $1-\mathrm{mm}$-wide veins are now $1-1.5$ $\mathrm{cm}$ wide. Fibrous chalcedony fills the center of many of these veins, in some cases with quartz and late-stage calcite.

\section{Celadonite-Type Alteration}

In several saponite-assemblage samples, celadonite, and Fe-oxyhydroxide line the walls of veins containing the minerals described previously. Fe-oxyhydroxides also occur with later calcite and chalcedony in some of these veins (Fig. 5A). In some cases celadonite and $\mathrm{Fe}$-oxyhydroxide replace the wallrock of the vein for up to a few hundred micrometers and, along with saponite, generally replace 


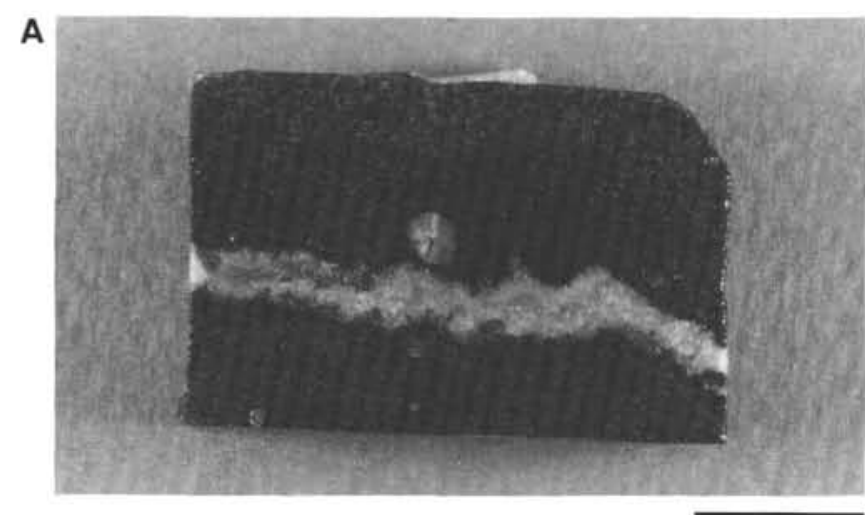

$1 \mathrm{~cm}$
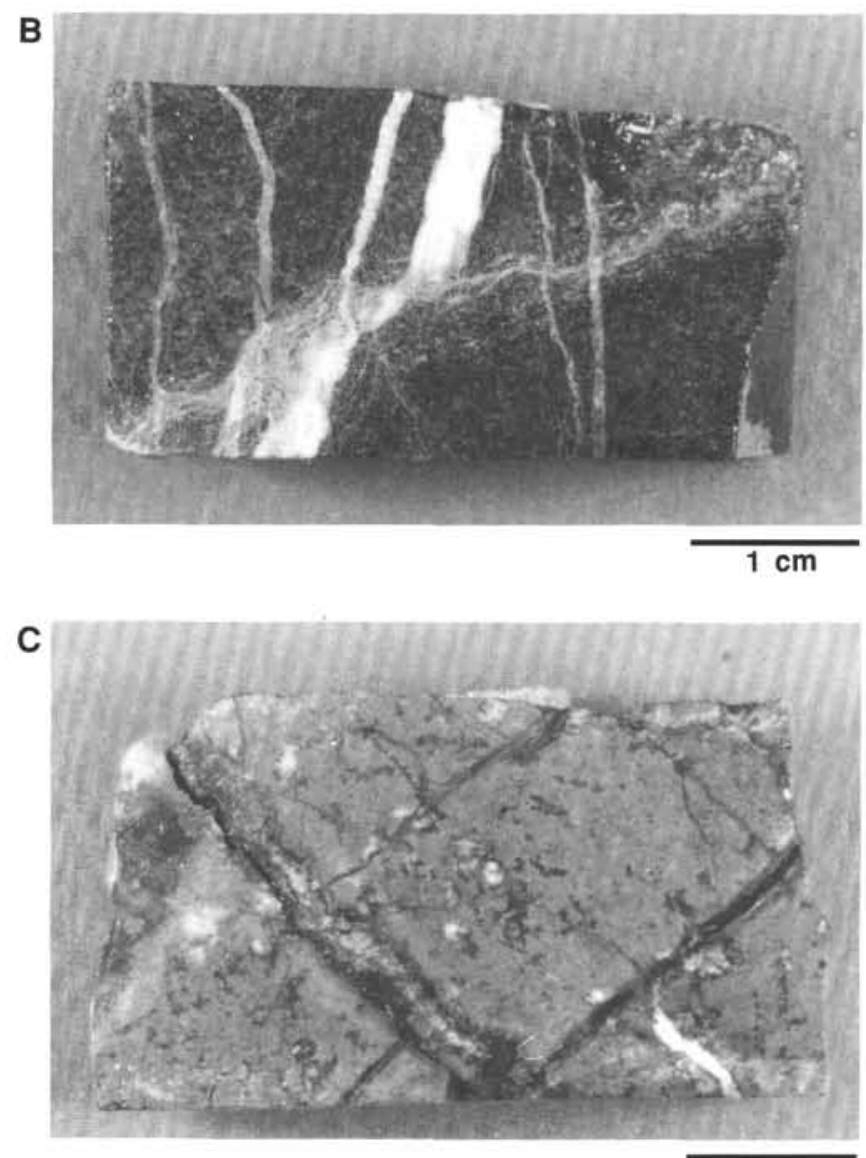

Figure 3. Photographs of Site 801 basalts exhibiting different alteration types. A. Saponite-type alteration, with calcite vein and calcite (white) and pyrite (black) in vesicles in dark gray rock. Sample 129-801C-9R-4, 38-43 cm. B. $\mathrm{Al}$-saponite-type alteration. Diagonal $\mathrm{Al}$-saponite vein in brown-colored rock is cut by numerous later calcite veins (white). Sample 129-801C-1R-6, 65-70 cm. C. Blue-green-type alteration. Extensively altered rock with altered plagioclase phenocrysts (white) is cut by veins of celadonite, glauconite, $\mathrm{Fe}$-oxyhydroxides, and $\mathrm{Al}$-smectite (montmorillonite-beidellite). Millimeter-wide reddish zones of $\mathrm{Fe}$-oxyhydroxides occur along veins (dark gray). Sample 129-801C-5R-1, 93-98 cm. olivine and fill vesicles and pore space for several millimeters around the celadonite-bearing veins. The Fe-oxyhydroxides impart a slight brownish color to the rocks. The celadonites are $\mathrm{K}$ - and Fe-rich, containing 5.0 to $9.7 \mathrm{wt} \% \mathrm{~K}_{2} \mathrm{O}$ and having $\mathrm{Fe} / \mathrm{Fe}+\mathrm{Mg}$ ratios of 0.5 to 0.8 (Fig. 4 and Table 1). The lower $\mathrm{K}_{2} \mathrm{O}$ contents of a few samples suggest that smectite may be present in these cases. Microprobe analyses and structural formulas indicate low $\mathrm{Al}$ contents $\left(<0.5\right.$ atoms per $\left.\mathrm{O}_{10}(\mathrm{OH})_{2}\right)$, with no $\mathrm{Al}$ in tetrahedral positions. These samples not only differ in containing celadonite and $\mathrm{Fe}$-oxyhydroxides rather than pyrite, but also have characteristic chemical changes distinct from the saponite-bearing rocks, and are thus considered as a second alteration type.

\section{Al-Saponite-Type Alteration}

A third alteration type occurs in the alkali basalts, but only in those from Hole $801 \mathrm{C}$. The rocks are dark brownish gray to light brown in color (Fig. 3B). These rocks are 50\%-100\% altered, and are characterized by the presence of $\mathrm{Al}$-saponite. $\mathrm{Al}$-saponite is distinguished optically from saponite by its paler color and chemically by its high $\mathrm{Al}_{2} \mathrm{O}_{3}$ content (11-14 wt \% vs. $<8$ wt $\%$; Fig. 4 and Table 1). The $\mathrm{Al}$-saponites are generally trioctahedral, with octahedral cations totaling about three atoms and with approximately one $\mathrm{Al}$ atom in tetrahedral positions per formula $\mathrm{O}_{10}(\mathrm{OH})_{2}$. Some analyses range to lower octahedral cation totals of $2.3-2.5$, however, indicating a partly dioctahedral structure. Calculated formulas have low tetrahedral $\mathrm{Al}$ $\left(0.1-0.2\right.$ atoms per $\left.\mathrm{O}_{10}(\mathrm{OH})_{2}\right)$, suggesting the presence of saponite mixed with or transitional to montmorillonite.

Olivine is completely replaced by Al-saponite, or by saponite in the less-altered rocks. Plagioclase is generally $20 \%-30 \%$ altered, but is up to $100 \%$ altered in some samples, mainly to $\mathrm{Al}$-saponite (Fig. 5B). Natrolite and calcite also replace plagioclase in lesser amounts in some samples. Clinopyroxene ranges from unaltered in the least altered samples to nearly $100 \%$ altered. The fine-grained, fibrous pyroxene is cloudy and is replaced by clay minerals and calcite, but the very fine grain size of both pyroxene and secondary phases makes identification difficult. Pore space in the rocks is filled with $\mathrm{Al}$-saponite and calcite. Veins in the rocks consist of $\mathrm{Al}$-saponite \pm calcite $\pm \mathrm{Fe}$-oxyhydroxide \pm pyrite. Clay mineral veins are generally 100 to $500 \mu \mathrm{m}$ wide, but multiple generations of calcite have resulted in veins up to $2 \mathrm{~mm}$ wide.

\section{Blue-Green-Type Alteration}

The fourth alteration type is characterized by the light blue-green color of the rocks (Fig. 3C) and is restricted to a single primitive tholeiitic cooling unit from 531 to 535 mbsf, immediately below the siliceous hydrothermal deposit. The rocks are highly altered, ranging from $80 \%$ recrystallized for a few samples in the interior of the unit to $100 \%$ for the remainder (Busch et al., this volume). The rocks are also highly fractured, forming a net-vein breccia at about $532.5 \mathrm{mbsf}$. Phyllosilicates include Al-smectite (montmorillonite-beidellite), glauconite, and celadonite. Glauconite is distinguished optically from celadonite in these rocks by the paler green color of glauconite. Chemically, the glauconites in these rocks have higher $\mathrm{Al}$ contents than celadonite (11.1-15.7 wt \% vs. $<7.7 \mathrm{wt} \%$, respectively), with tetrahedral $\mathrm{Al}$ contents of $0.1-0.17$ atoms per formula $\mathrm{O}_{10}(\mathrm{OH})_{2}$ (Fig. 4 and Table 1). The Al-smectites are dioctahedral and $\mathrm{Al}$ rich, containing $22-35 \mathrm{wt} \% \mathrm{Al}_{2} \mathrm{O}_{3}$ (Fig. 4 and Table 1). The layer charge is distributed subequally between octahedral and tetrahedral layers, indicating a structure intermediate between montmorillonite and beidellite.

Olivine is $100 \%$ replaced by $\mathrm{Al}$-smectite, glauconite, and calcite. Plagioclase is slightly altered to nearly totally replaced by Al-smectite, glauconite, K-feldspar, natrolite, and lesser calcite (Fig. 5C), Fine-grained fibrous groundmass clinopyroxene is slightly to extensively altered, appearing cloudy due to replacement by clays and calcite. Titanomagnetite is completely replaced by granular sphene. Pore space in the rocks is filled with $\mathrm{Al}$-smectite, glauconite, and 
celadonite. Veins comprise $15 \%-25 \%$ of the recovered material, ranging from 0.1 to $7 \mathrm{~mm}$ wide. These are filled with clay minerals and calcite, with the general sequence (1) glauconite $\pm \mathrm{Fe}$-oxyhydroxide, (2) \pm Al-smectite, (3) \pm calcite, (4) chalcedony \pm quartz, and (5) \pm late calcite. Celadonite $\pm \mathrm{Fe}$-oxyhydroxide veins are also present.

The rocks immediately above and below the hydrothermal deposit in Core $129-801 \mathrm{C}-4 \mathrm{R}$ are oxidized and stained by $\mathrm{Fe}$-oxyhydroxides. The blue-green altered tholeiites just below the deposit range from yellow to red in color, with an abrupt boundary that changes to the blue-green color at $35 \mathrm{~cm}$ in Section 129-801C-5R-1. The Al-saponitebearing alkali basalts above the deposit are stained brown by $\mathrm{Fe}$-oxyhydroxides in the lowermost 10-15 cm of Core 129-801C-3R.

\section{Hydrothermal Deposit}

The hydrothermal deposit comprises essentially all of Core 129 . $801 \mathrm{C}-4 \mathrm{R}$. Approximately $3 \mathrm{~m}$ of material was recovered from the 9.5-m drilled interval (521.7-531.2 mbsf). At least some recrystallized sediment is present at the top of the deposit (e.g., Sample 129-801C-4R-1, 32-36 cm, consists of layered crystalline calcite with minor amounts of clay mineral [saponite]). The hydrothermal deposit consists of bright yellow-orange ochreous material with irregular banding, much of which is disrupted or broken and cemented by silica (Fig. 6A). In the thin section of Sample 129-801C-4R-1, 100-106 cm, the material is composed of 5 - to $200-\mu \mathrm{m}$ spherules and aggregates of orange to red Fe-oxyhydroxide. This material is silicified and cemented by granular, fine-grained $(10-100 \mu \mathrm{m})$ quartz. The uniform granular texture of much of the quartz is similar to that formed by recrystallization of opal spherules in other siliceous seafloor hydrothermal deposits (Alt et al., 1987), suggesting a possibly similar origin for some of the quartz in the Hole 801C deposit. Multiple late-stage coarse quartz veins crosscut the deposit, and open vugs are lined with coarse quartz crystals.

Thread-like filaments of orange Fe-oxyhydroxide are locally present in the deposit. These filaments are mostly curved and branching, about $5 \mu \mathrm{m}$ wide and $50-100 \mu \mathrm{m}$ long (Fig. 6B, 6C). Double-twisted spiral filaments, up to $200 \mu \mathrm{m}$ in length, also occur. The morphologies of these filaments are remarkably similar to those of some genera of $\mathrm{Fe}$-oxidizing bacteria. In particular, the double spirals are identical to Gallionella (Buchanan and Gibbons, 1974). The Fe-oxide material in the hydrothermal deposit, including the filaments, is nearly identical to that in Fe-oxide deposits described from seamounts and mid-ocean ridges, and which are actively forming at temperatures of around $10^{\circ}-15^{\circ} \mathrm{C}$ (Alt, 1988; Juniper and Fouquet, 1988). By analogy with such Fe deposits, the hydrothermal deposit in Hole 801C is interpreted as a low-temperature $\mathrm{Fe}$-oxyhydroxide precipitate that was later silicified and cut by quartz veins.

\section{Whole-rock Chemical Changes}

The whole-rock chemical analyses discussed in this paper are given in the "Summary of Geochemical Data" chapter (Castillo et al., this volume). Chemical changes in the rocks are discussed here in terms of the four alteration types and alkalic vs. tholeiitic basalt.

Because the main alteration phases in the tholeiites are hydrous (saponite and celadonite), $\mathrm{H}_{2} \mathrm{O}$ content of the rocks can be used as an indicator of extent of alteration. Two different trends can be seen on a plot of $\mathrm{K}_{2} \mathrm{O}$ vs. $\mathrm{H}_{2} \mathrm{O}$ (Fig. 7). $\mathrm{H}_{2} \mathrm{O}$ increases without a corresponding change in $\mathrm{K}_{2} \mathrm{O}$ at low $\mathrm{H}_{2} \mathrm{O}$ contents $(<1 \mathrm{wt} \%)$, whereas both $\mathrm{K}_{2} \mathrm{O}$ and $\mathrm{H}_{2} \mathrm{O}$ increase at higher $\mathrm{H}_{2} \mathrm{O}$ contents $(>1 \mathrm{wt} \%)$. These two trends separate the two alteration types present in these rocks: $\mathrm{K}$-poor saponite-bearing rocks are hydrated but not enriched in $\mathrm{K}$, whereas $\mathrm{K}$-rich celadonite-bearing rocks are both hydrated and enriched in $\mathrm{K}$.

Like the $\mathrm{K}_{2} \mathrm{O}-\mathrm{H}_{2} \mathrm{O}$ plot there is little or no change in $\mathrm{MgO}, \mathrm{CaO}$, $\mathrm{Na}_{2} \mathrm{O}$, or $\mathrm{Fe}_{2} \mathrm{O}_{3} \mathrm{~T}$ at low $\mathrm{H}_{2} \mathrm{O}$ contents in the tholeiites $(<1 \mathrm{wt} \%$, Fig. 7). At higher $\mathrm{H}_{2} \mathrm{O}$ contents, however, slight decreases of these elements occur, most notably $\mathrm{CaO}$ but also $\mathrm{MgO}$ in the tholeiites. In
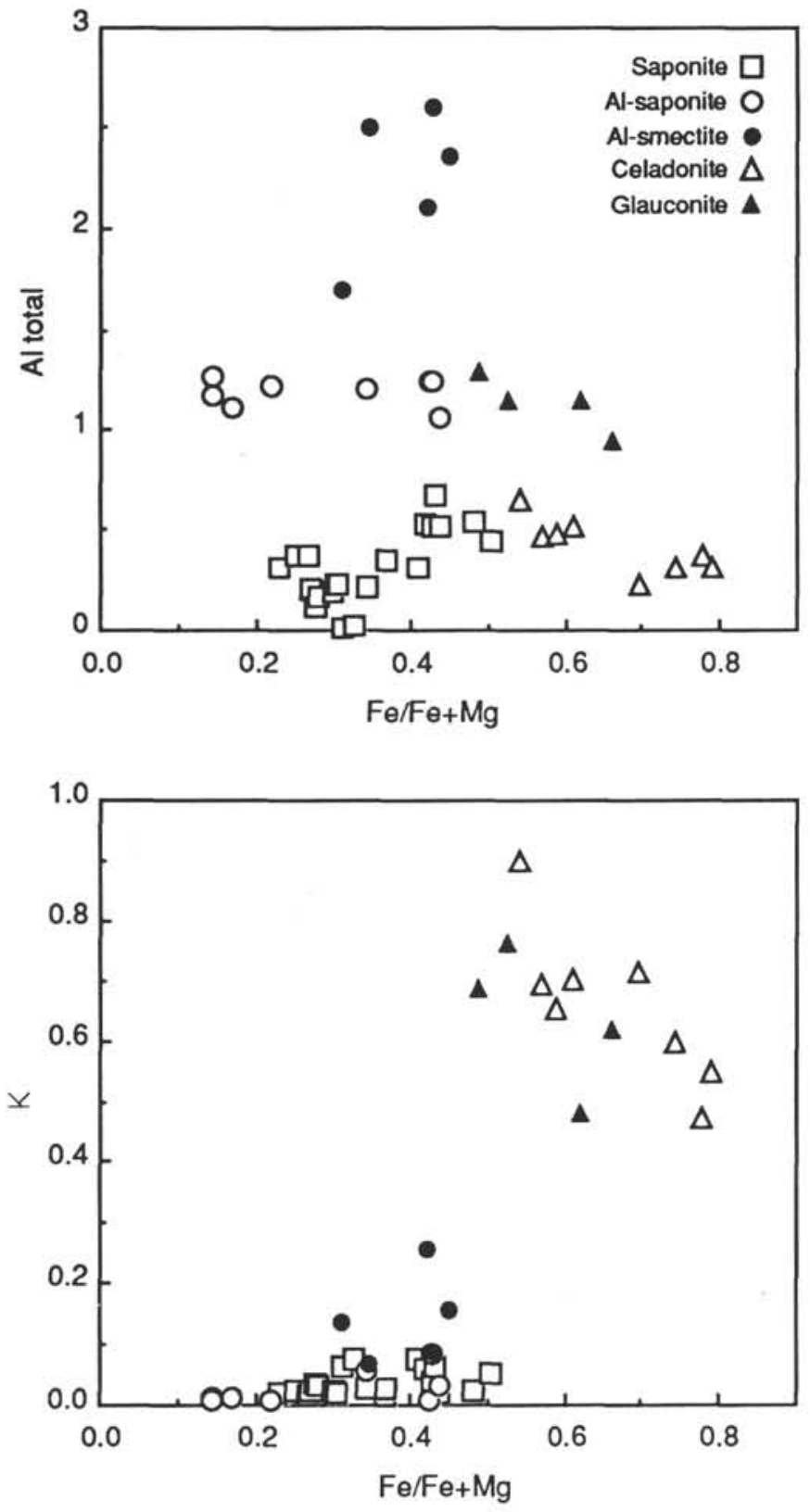

Figure 4. Compositional data for secondary phyllosilicates from Site 801 basement. Atomic contents per structural formula $\mathrm{O}_{10}(\mathrm{OH})_{2}$.

contrast, there is a direct increase in $\mathrm{Fe}^{3+} / \mathrm{Fe}^{\mathrm{T}}$ with $\mathrm{H}_{2} \mathrm{O}$ content (Fig. 7). These chemical changes reflect hydration and slight oxidation with little corresponding other chemical changes during saponitetype alteration in the tholeiites. The only other change appears to be increased $\delta^{18} \mathrm{O}$ values (see "Oxygen and Carbon Isotopes" section, this chapter).

The increased $\mathrm{K}_{2} \mathrm{O}$ and $\mathrm{Rb}$ and loss of $\mathrm{Mg}$ at higher $\mathrm{H}_{2} \mathrm{O}$ contents reflect the formation of $\mathrm{K}$-rich, $\mathrm{Mg}$-poor (compared to saponite) celadonite in the rocks. Slight alteration of plagioclase probably contributes to the scatter in $\mathrm{CaO}$ and $\mathrm{Na}_{2} \mathrm{O}$ contents at higher $\mathrm{H}_{2} \mathrm{O}$ contents (Fig. 7). The samples with the highest $\mathrm{CaO}$ contents also have high $\mathrm{CO}_{2}$ contents, indicating that secondary calcite contributes to the scatter in $\mathrm{CaO}$. Increased $\mathrm{K}_{2} \mathrm{O}$ in the tholeiites correlates with increased $\mathrm{Fe}^{3+} / \mathrm{Fe}^{\mathrm{T}}$ (Fig. 8), indicating oxidation of $\mathrm{Fe}$ during celadonite and Fe-oxyhydroxide formation. Sulfur contents of both saponite and celadonite alteration types decrease with increased $\mathrm{Fe}^{3+} / \mathrm{Fe}^{\mathrm{T}}$ due to 
Table 1. Representative electron microprobe analyses of secondary phyllosilicates in Hole $801 C$ basement.

\begin{tabular}{|c|c|c|c|c|c|c|}
\hline $\begin{array}{l}\text { Core, section: } \\
\text { Interval }(\mathrm{cm}) \text { : }\end{array}$ & $\begin{array}{c}7 R-3 \\
110-116\end{array}$ & $\begin{array}{c}1 \mathrm{R}-1 \\
120-125\end{array}$ & $\begin{array}{c}1 \mathrm{R}-6 \\
65-70\end{array}$ & $\begin{array}{c}5 \mathrm{R}-1 \\
93-98 \\
\begin{array}{c}\text { Montmorillonite- } \\
\text { beidellite }\end{array}\end{array}$ & $\begin{array}{c}5 R-1 \\
93-98\end{array}$ & $\begin{array}{c}7 R-3 \\
53-59\end{array}$ \\
\hline \multicolumn{7}{|l|}{$(w t \%)$} \\
\hline $\mathrm{SiO}_{2}$ & 52.94 & 38.99 & 52.16 & 52.58 & 55.15 & 52.03 \\
\hline $\mathrm{Al}_{2} \mathrm{O}_{3}$ & 2.77 & 13.82 & 14.15 & 30.79 & 15.72 & 2.43 \\
\hline $\mathrm{MgQ}$ & 19.32 & 22.90 & 9.06 & 2.49 & 4.86 & 5.30 \\
\hline $\mathrm{FeO}^{1}$ & 15.25 & 11.48 & 8.46 & 3.62 & 9.13 & 24.01 \\
\hline $\mathrm{MnO}$ & 0.02 & 0.29 & 0.07 & 0.05 & 0.09 & 0.00 \\
\hline $\mathrm{CaO}$ & 0.91 & 0.99 & 1.04 & 1.58 & 0.72 & 0.42 \\
\hline $\mathrm{Na}_{2} \mathrm{O}$ & 0.15 & 0.17 & 0.25 & 0.12 & 0.04 & 0.02 \\
\hline $\mathrm{K}_{2} \mathrm{O}$ & 0.23 & 0.10 & 0.62 & 1.88 & 7.73 & 7.10 \\
\hline $\mathrm{TiO}_{2}$ & 0.10 & 0.11 & 0.01 & & & 0.06 \\
\hline Total & 91.70 & 88.85 & 85.82 & 93.11 & 93.44 & 91.37 \\
\hline \multicolumn{7}{|l|}{ (atoms) } \\
\hline $\mathrm{Si}$ & 3.788 & 2.902 & 3.782 & 3.416 & 3.840 & 4.107 \\
\hline Al IV & 0.212 & 1.098 & 0.218 & 0.584 & 0.160 & \\
\hline IV total & 4.000 & 4.000 & 4.000 & 4.000 & 4.000 & 4.107 \\
\hline Al VI & 0.022 & 0.114 & 0.991 & 1.771 & 1.129 & 0.226 \\
\hline $\mathrm{Mg}$ & 2.059 & 2.539 & 0.979 & 0.241 & 0.504 & 0.623 \\
\hline $\mathrm{Fe}$ & 0.910 & 0.713 & 0.512 & 0.196 & 0.477 & 1.423 \\
\hline $\mathrm{Mn}$ & 0.001 & 0.018 & 0.004 & 0.003 & 0.005 & 0.000 \\
\hline $\mathrm{Ti}$ & 0.005 & 0.006 & 0.001 & 0.000 & 0.000 & 0.004 \\
\hline VI total & 2.997 & 3.390 & 2.487 & 2.211 & 2.115 & 2.276 \\
\hline $\mathrm{Ca}$ & 0.070 & 0.079 & 0.081 & 0.110 & 0.054 & 0.036 \\
\hline $\mathrm{Na}$ & 0.021 & 0.024 & 0.035 & 0.015 & 0.005 & 0.003 \\
\hline $\mathrm{K}$ & 0.021 & 0.009 & 0.057 & 0.156 & 0.686 & 0.715 \\
\hline Interlayer & 0.112 & 0.112 & 0.173 & 0.281 & 0.745 & 0.754 \\
\hline
\end{tabular}

Notes: Structural formulas calculated on the basis of $\mathrm{O}_{10}(\mathrm{OH})_{2}$. Fe assumed to be $\mathrm{Fe}^{3+}$ in celadonite and glauconite, and as $\mathrm{Fe}^{2+}$ in all other analyses.

oxidation of igneous sulfides (Fig. 8). Thus, excluding the blue-green altered tholeiites immediately below the hydrothermal deposit (from 531 to $535 \mathrm{mbsf}$ ), the tholeiites from the lower half of the hole exhibit clear trends toward increased $\mathrm{K}_{2} \mathrm{O}, \mathrm{Rb}, \mathrm{Fe}^{3+} / \mathrm{Fe}^{\mathrm{T}}, \mathrm{H}_{2} \mathrm{O}$, and $\mathrm{CO}_{2}$ due to alteration (Fig. 2). Local slight variations in $\mathrm{Fe}_{2} \mathrm{O}_{3}{ }^{\mathrm{T}}, \mathrm{MnO}, \mathrm{MgO}$, $\mathrm{CaO}$, and $\mathrm{Na}_{2} \mathrm{O}$ are also be attributed to alteration.

The blue-green altered rocks below the hydrothermal deposit are the most extensively altered rocks in the tholeiite section. They exhibit chemical trends similar to those of the underlying rocks, but have gained greater amounts of $\mathrm{K}_{2} \mathrm{O}, \mathrm{Rb}, \mathrm{Fe}^{3+} / \mathrm{Fe}^{\mathrm{T}}, \mathrm{H}_{2} \mathrm{O}$, and $\mathrm{CO}_{2}$ and many have clearly lost $\mathrm{Fe}_{2} \mathrm{O}_{3}{ }^{\mathrm{T}}, \mathrm{MnO}, \mathrm{MgO}, \mathrm{CaO}$, and $\mathrm{Na}_{2} \mathrm{O}$ (see primitive tholeiites in Fig. 2). These are especially evident for the high- $\mathrm{H}_{2} \mathrm{O}$ blue-green samples (all primitive tholeiites) in Figure 7. The bluegreen rocks are also slightly enriched in $\mathrm{Ba}$ relative to unaltered tholeiites (about 150 parts per million, or ppm, vs. 10-20 ppm, see "Summary of Geochemical Data" chapter, Castillo et al., this volume). There is no correlation of changes in metal contents $(\mathrm{Cu}, \mathrm{Zn}, \mathrm{Ni}, \mathrm{Cu}$, and $\mathrm{Pb}$ ) with alteration in the blue-green rocks. The high $\mathrm{H}_{2} \mathrm{O}$ contents are due to the nearly complete recrystallization of the rocks to secondary minerals. The decreases in $\mathrm{CaO}$ and $\mathrm{Na}_{2} \mathrm{O}$ and increases in $\mathrm{K}_{2} \mathrm{O}$ and $\mathrm{Rb}$ are attributed to the breakdown of plagioclase and formation of secondary K-feldspar, glauconite, and celadonite.

The alkali basalts in the upper half of the core affected by saponite-, celadonite-, and Al-saponite-type alteration exhibit trends of increased $\mathrm{K}_{2} \mathrm{O}, \mathrm{Rb}, \mathrm{Fe}^{3+} / \mathrm{Fe}^{\mathrm{T}}, \mathrm{H}_{2} \mathrm{O}$, and $\mathrm{CO}_{2}$ and some variations in $\mathrm{Na}_{2} \mathrm{O}, \mathrm{CaO}$, and $\mathrm{MnO}$ with alteration, similar to the trends in the tholeiite section (Fig. 2). Even though unaltered starting concentrations of $\mathrm{K}_{2} \mathrm{O}, \mathrm{Rb}$, and $\mathrm{H}_{2} \mathrm{O}$ and $\mathrm{Fe}^{3+} / \mathrm{Fe}^{\mathrm{T}}$ values are higher than in the tholeiites, altered alkali basalts reach higher values for these elements than the tholeiites (Fig. 2). This reflects the greater extent of alteration of the alkali basalts than the tholeiites ( $>30 \%$ vs. $10 \%-20 \%$, respectively).

Like the tholeiites, the alkali basalts fall into two general groups on $\mathrm{H}_{2} \mathrm{O}$ plots (Fig. 7). There is little chemical change with increasing
$\mathrm{H}_{2} \mathrm{O}$ at low $\mathrm{H}_{2} \mathrm{O}$ contents. In particular, the primitive alkali basalts from 488 to 495 mbsf exhibit no $\mathrm{K}_{2} \mathrm{O}$ or Rb gain, but have high $\mathrm{H}_{2} \mathrm{O}$ contents, reflecting extensive alteration to $\mathrm{K}$-poor saponite. These rocks are slightly oxidized (Fig. 7), but exhibit little or no other chemical changes due to alteration.

At higher $\mathrm{H}_{2} \mathrm{O}$ contents, $\mathrm{K}_{2} \mathrm{O}, \mathrm{Rb}$, and $\mathrm{Fe}^{3+} / \mathrm{Fe}^{\mathrm{T}}$ increase and $\mathrm{CaO}$ and $\mathrm{Na}_{2} \mathrm{O}$ decrease due to celadonite- and $\mathrm{Al}$-saponite-type alteration. The alkali basalts with the highest $\mathrm{H}_{2} \mathrm{O}$ and $\mathrm{K}_{2} \mathrm{O}$ contents are also the most oxidized (Figs. 7 and 8). These rocks have lost significant amounts of $\mathrm{CaO}$ and $\mathrm{Na}_{2} \mathrm{O}$ due to the breakdown of plagioclase and clinopyroxene during Al-saponite type alteration. The rocks affected by $\mathrm{Al}$-saponite alteration are the most extensively altered alkali basalts and thus exhibit the greatest chemical changes.

A sample of interpillow material from $587.4 \mathrm{mbsf}$ was also chemically analyzed (Table 2). This sample consists of volcanic glass replaced by saponite, celadonite, and calcite, and cemented by clots of celadonite and saponite containing spherules of chalcedony, in turn, cemented by calcite and fibrous chalcedony. This material has very high $\mathrm{CaO}$ and $\mathrm{CO}_{2}$ contents ( $23 \%$ and $19 \%$, respectively), high $\mathrm{MnO}, \mathrm{K}_{2} \mathrm{O}, \mathrm{Rb}$, and $\mathrm{H}_{2} \mathrm{O}$ contents, high $\mathrm{Fe}^{3+} / \mathrm{Fe}^{\mathrm{T}}$, and low $\mathrm{Na}_{2} \mathrm{O}$, $\mathrm{Fe}_{2} \mathrm{O}_{3}{ }^{\mathrm{T}}$, and $\mathrm{MgO}$ compared with the altered rocks (Fig. 2).

One sample of the hydrothermal deposit was chemically analyzed (Table 2). The material consists essentially of silica ( $86.5 \%$ ) and iron $\left(9.97 \% \mathrm{Fe}_{2} \mathrm{O}_{3}{ }^{\mathrm{T}}\right)$, with all iron ferric. It contains less than $0.2 \% \mathrm{MgO}$ and $\mathrm{Al}_{2} \mathrm{O}_{3}$ and less than $0.1 \% \mathrm{TiO}_{2}, \mathrm{CaO}, \mathrm{Na}_{2} \mathrm{O}, \mathrm{K}_{2} \mathrm{O}$, and $\mathrm{P}_{2} \mathrm{O}_{5}$. The sample is enriched in $\mathrm{Ba}$ compared with the underlying tholeiites (74 ppm vs. about $10-20 \mathrm{ppm})$, and is relatively depleted in transition metals $(\mathrm{Cu}, \mathrm{Ni}$, and $\mathrm{Zn})$.

\section{Oxygen and Carbon Isotopes}

Whole-rock $\delta^{18} \mathrm{O}$ values are given in Table 3. Three alkali basalts range from $+11.2 \%$ to $+18.9 \%$, whereas the four tholeiites analyzed 

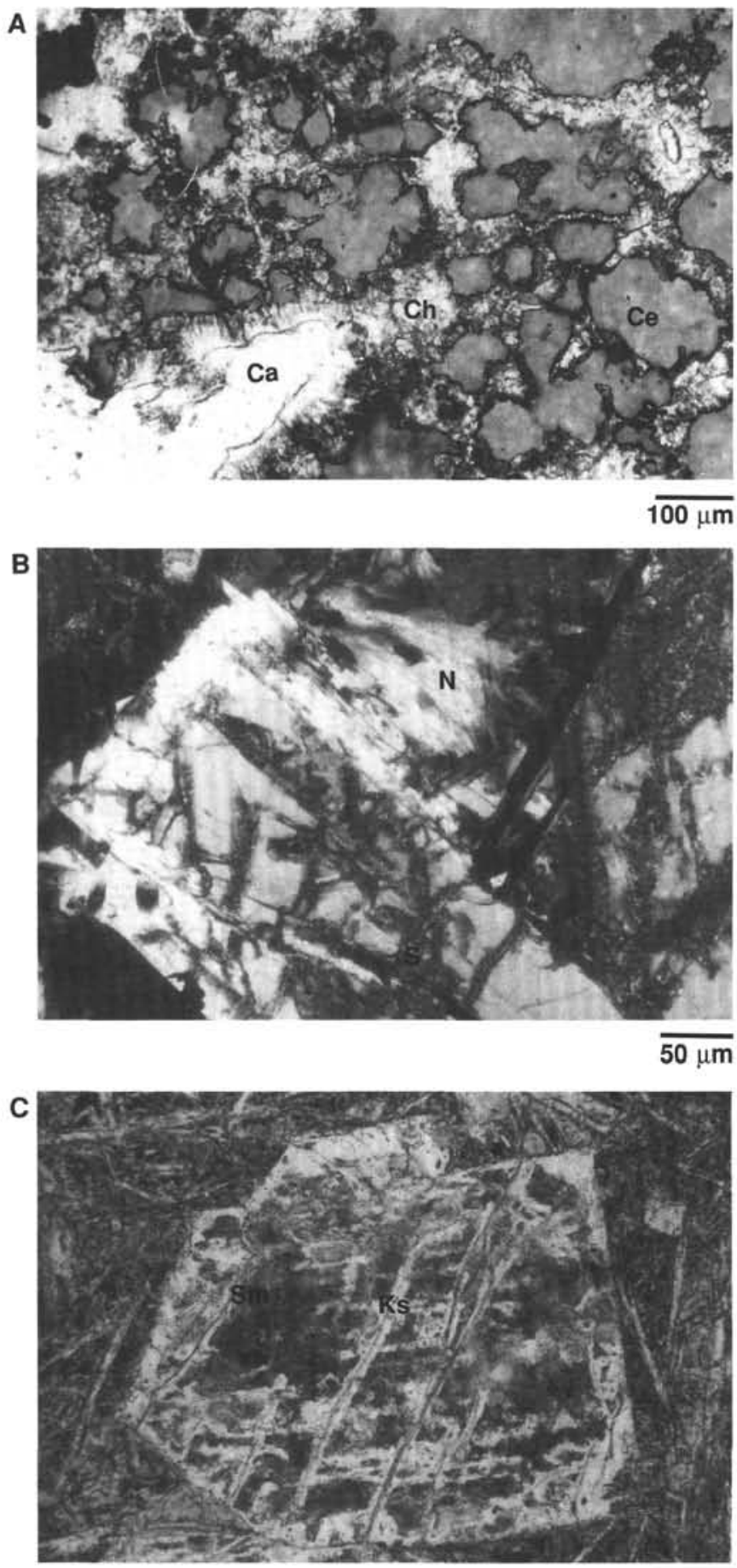

$\overline{100 \mu \mathrm{m}}$

Figure 5. Thin-section photomicrographs of secondary minerals in Site 801 basement. A. Vein containing celadonite (gray, Ce) cemented by chalcedony (white, Ch) and calcite (white, Ca). Sample 129-801C-7R-3, 53-59 cm. B. Plagioclase phenocryst partly replaced by $\mathrm{Al}$-saponite (dark gray, S) and natrolite $(\mathrm{N})$. Al-saponite type alteration, Sample 129-801C-1R-6, 65-70 cm. C. Plagioclase phenocryst completely replaced by $\mathrm{K}$-feldspar along fractures (white, Ks) and Al-smectite (sm). Sample 129-801C-5R-1, 93-98 cm.
A

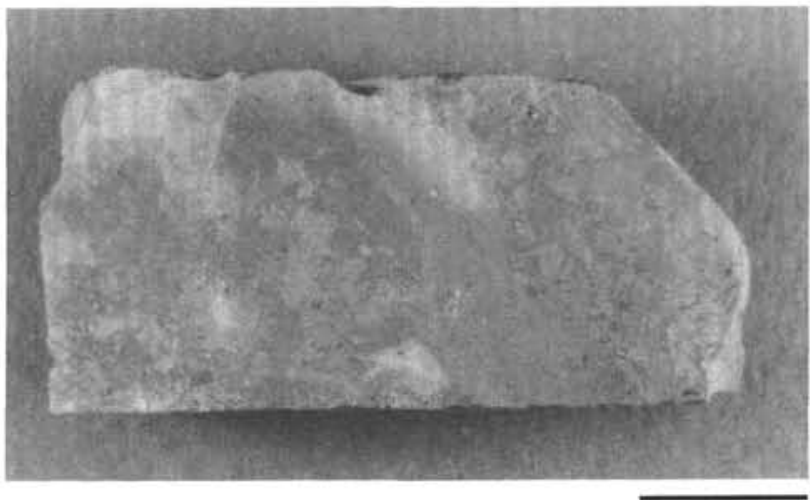

$1 \mathrm{~cm}$
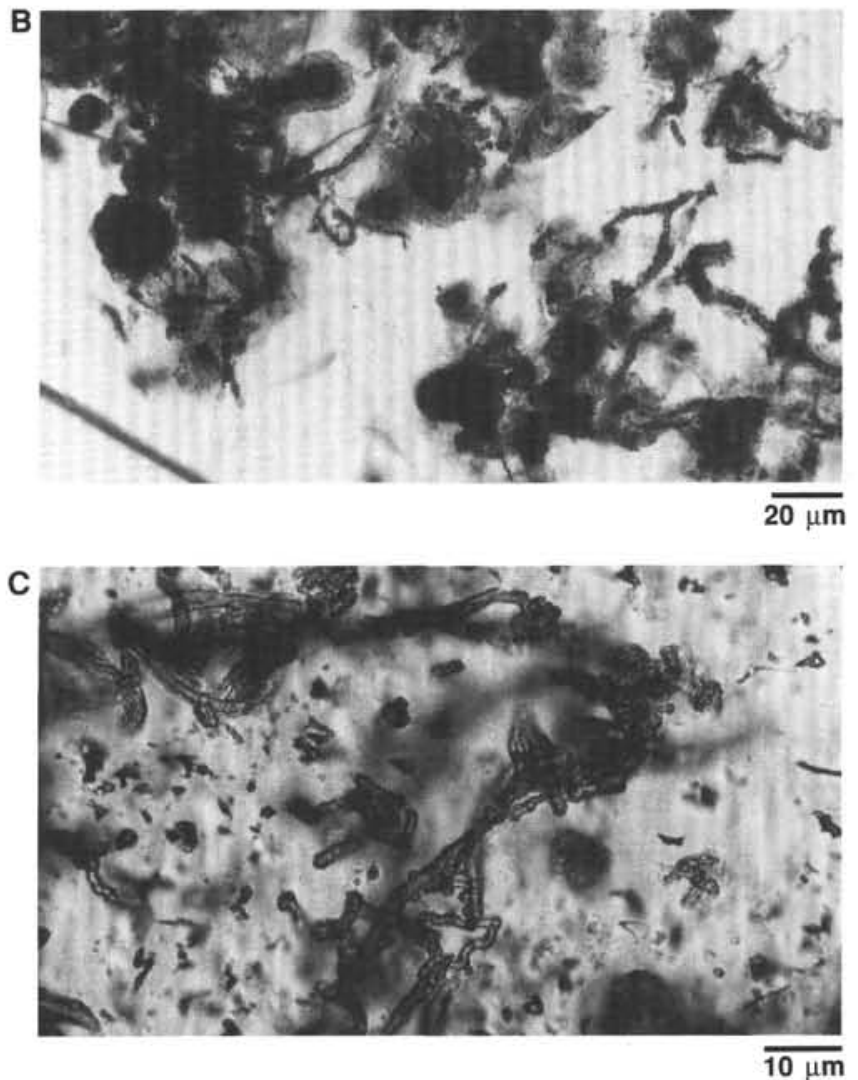

Figure 6. Hydrothermal deposit from Hole 801C. Sample 129-801C-4R-1, $100-106 \mathrm{~cm}$. A. Hand specimen showing disrupted structure (top is to the right). B. Photomicrograph showing spherules, aggregates, and filaments of Fe-oxyhydroxide (gray) surrounded by quartz (white). C. Close-up of filamentous material showing curved and branching structures.

have lower values of $+6.5 \%$ to $+8.0 \%$ (Fig. 9). All these samples are from the saponite, celadonite, or Al-saponite alteration types. The rocks are enriched in ${ }^{18} \mathrm{O}$ relative to fresh basalts, which average $+5.7 \%$ for MORB and $+6.1 \%$ for ocean-island alkali basalt (Muehlenbachs and Clayton, 1972; Kyser, 1986). Such ${ }^{18} \mathrm{O}$ enrichments are characteristic of seafloor basalts that have reacted with seawater at low temperatures (about $0^{\circ}-50^{\circ} \mathrm{C}$, Muehlenbachs and Clayton, 1972; Bohlke et al., 1984). The greater ${ }^{18} \mathrm{O}$ enrichment of the alkali basalts compared to the tholeiites can be attributed in part to the slightly higher $\delta^{18} \mathrm{O}$ value for unaltered alkali basalt compared with unaltered MORB, but this can only account for about $0.5 \%$ of the 

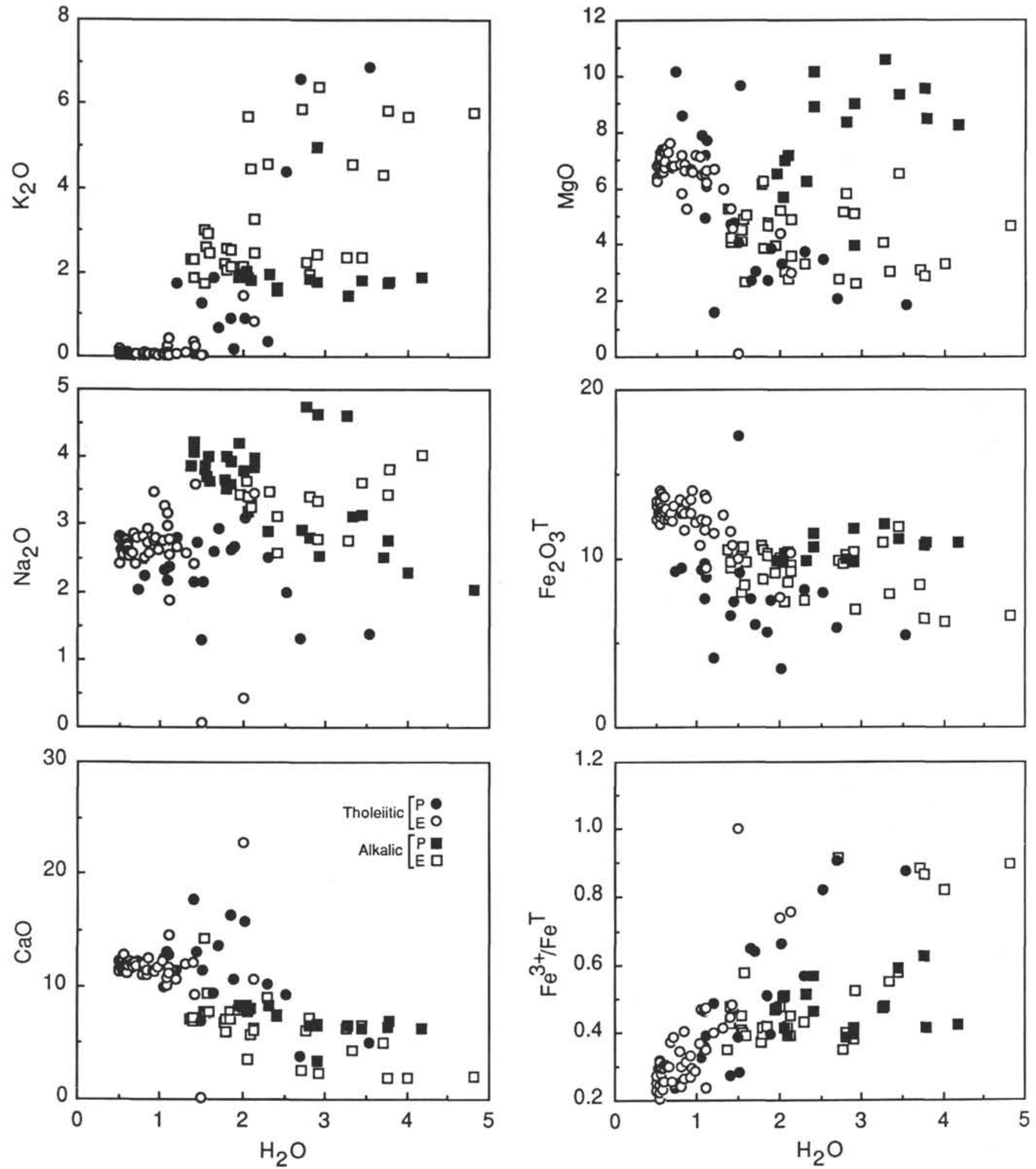

Figure 7. Oxides vs. $\mathrm{H}_{2} \mathrm{O}^{+}$plots. Contents in weight percent.

difference. The generally greater extent of recrystallization of the alkali basalts compared with the tholeiites $(30 \%-80 \%$ vs. $10 \%-20 \%$, respectively) must account for the correspondingly greater $\delta^{18} \mathrm{O}$ values of the alkali basalts.

Muehlenbachs and Clayton (1972) suggested that seafloor basalts altered at low temperatures could be modeled as a mixing line between fresh basalt and smectite on a $\delta^{18} \mathrm{O}-\mathrm{H}_{2} \mathrm{O}$ diagram. Bohlke et al. (1984) pointed out that variations in temperature and secondary mineral assemblage can complicate such a model, requiring slightly different mixing lines for different mineral assemblages and alteration temperatures. The analyses from Hole 801 are generally consistent with the smectite-basalt mixing model at temperatures of $0^{\circ}-50^{\circ} \mathrm{C}$ 

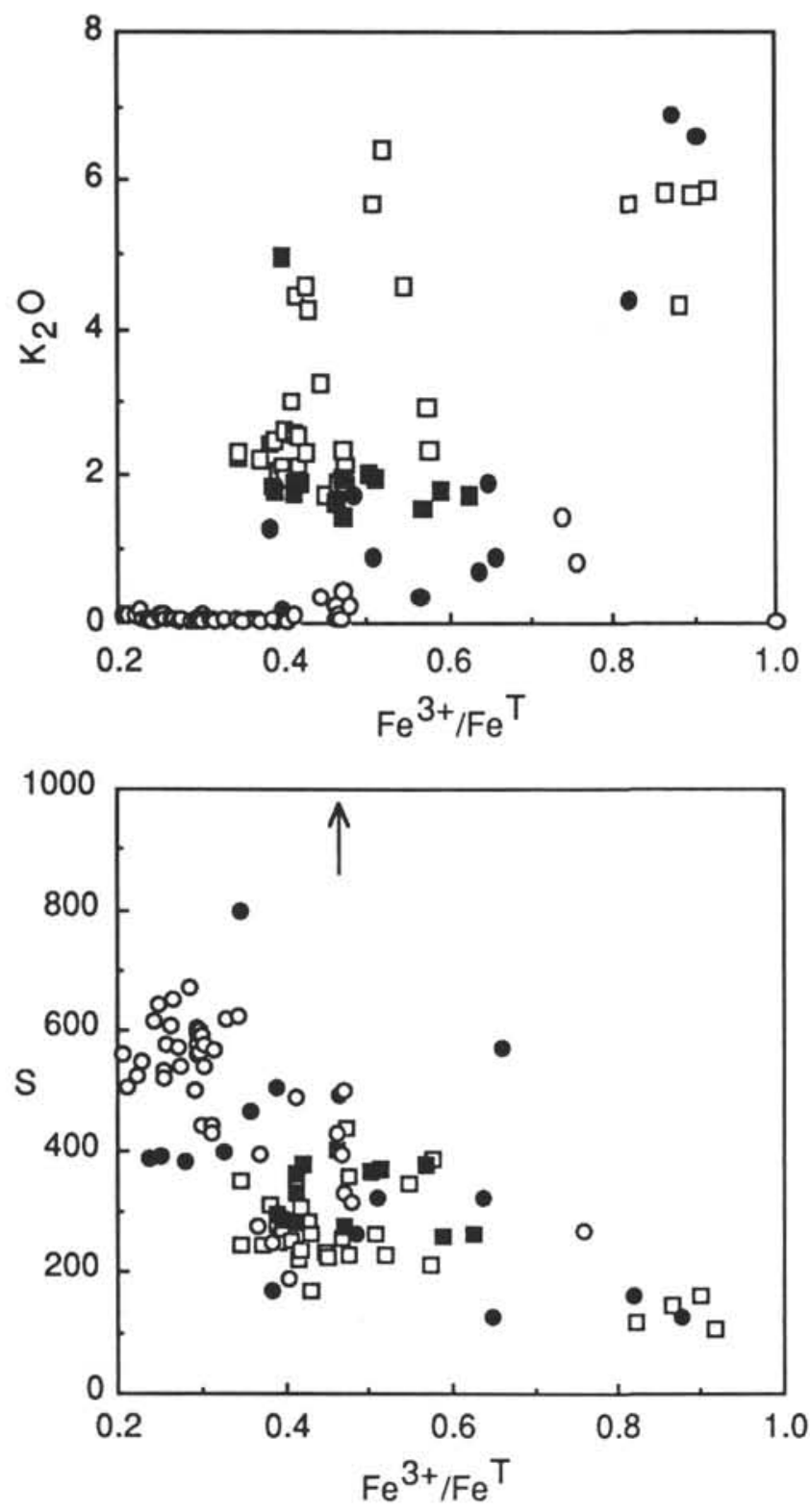

Figure 8. Iron oxidation plots. $\mathrm{K}_{2} \mathrm{O}$ in weight percent, $\mathrm{S}$ in ppm. Symbols as in Figure 2; arrow indicates sample that plots off scale.

(Fig. 9), with the higher $\delta^{18} \mathrm{O}-\mathrm{H}_{2} \mathrm{O}$ alkali basalts more extensively altered to smectite, and perhaps altered at somewhat higher temperatures (up to about $50^{\circ} \mathrm{C}$ ) than the tholeiites $\left(0^{\circ}-20^{\circ} \mathrm{C}\right.$ ). Slightly higher temperatures would have increased reaction rates and extent of alteration in the alkali basalts, resulting in the generally higher $\delta^{18} \mathrm{O}$ values of the alkali basalts. The duration of seawater circulation may also have been greater in the upper volcanic section, resulting in greater extent of low-temperature alteration and higher $\delta^{18} \mathrm{O}$ values of the alkali basalts (Muehlenbachs, 1979). The highest $\delta^{18} \mathrm{O}$ alkali basalt occurs at the top of the core in proximity to overlying cold seawater (Fig. 10), and may have been altered at somewhat lower temperatures or for a longer duration than the other alkalic basalts. The sample also likely contains relatively low- $\mathrm{H}_{2} \mathrm{O}$, high- $\delta^{18} \mathrm{O}$ secondary phases, such as calcite or zeolites, that would make the sample fall above the smectite trend in Figure 9 (Bohlke et al., 1984).

Carbonates separated from whole rocks and veins have $\delta^{18} \mathrm{O}$ values of $+24 \%$ to $+31 \%$ (Table 3 and Fig. 11). The siderite extracted at $150^{\circ} \mathrm{C}$ from one sample has a slightly lower $\delta^{18} \mathrm{O}$ than calcite from

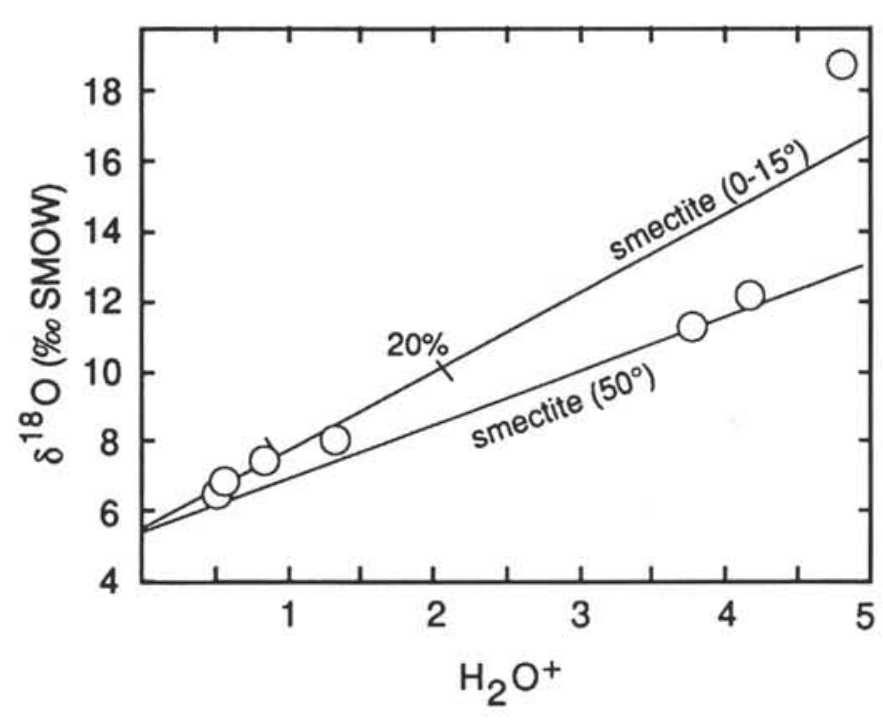

Figure 9. Whole-rock $\delta^{18} \mathrm{O}$ vs. $\mathrm{H}_{2} \mathrm{O}^{+}$for Site 801 basalts showing smectitebasalt mixing model of Muehlenbachs and Clayton (1972). Lines indicate

the same sample, consistent with experimentally determined fractionation (Carothers et al., 1988). The oxygen isotopic data for carbonates suggest temperatures of about $10^{\circ}-45^{\circ} \mathrm{C}$ if they formed in equilibrium with seawater (O'Neil et al., 1969) or somewhat lower temperatures if they formed from ${ }^{18} \mathrm{O}$-depleted fluids, such as in overlying pore waters (France-Lanord et al., this volume). These estimated temperatures are similar to those from the smectite mixing model in Figure 9 (i.e., $0^{\circ}-50^{\circ} \mathrm{C}$ ). Quartz from the hydrothermal deposit has $\delta^{18} \mathrm{O}=+28.0 \%$ (Table 3 ), indicating a temperature of $30^{\circ}-60^{\circ} \mathrm{C}$ if formed in equilibrium with normal seawater (Matsuhisa et al., 1979). These temperatures are consistent with the highest temperatures estimated for vein calcites and for the alkali basalts from the smectite mixing model, but are generally greater than present basement temperatures, which are estimated to range from about $14^{\circ} \mathrm{C}$ to $17^{\circ} \mathrm{C}$ with a gradient of about $2^{\circ} \mathrm{C} / 100 \mathrm{~m}$ (A. Fisher, pers. comm., 1990).

Carbonates have $\delta^{13} \mathrm{C}$ values of $+2 \%$ to $-8 \%$ (Table 3 and Fig. 11). The higher values $(-2 \%$ to $+2 \%$ ) are consistent with formation from normal seawater. The negative values occur mostly in the alkali basalts, where sediments are intercalated with the basalts, suggesting that a component of organic carbon from intercalated or overlying sediments was present in the carbonate-forming fluids. Closed-system evolution of fluid carbon isotopic compositions or contributions of mantle $\mathrm{CO}_{2}$ can also contribute to such low $\delta^{13} \mathrm{C}$ values for carbonates in altered basalts (Lawrence, 1991), but given the proximity of the Site 801 veins to sediments, the organic carbon contribution appears most likely.

\section{DISCUSSION}

Any discussion of alteration of the crust at Site 801 must include some interpretation for the origin of the crustal section, with the alkali basalts overlying tholeiites. Floyd and Castillo (this volume) and Castillo et al. (this volume) interpreted the tholeiites as N-MORB that represent typical oceanic crust formed at a Jurassic mid-ocean ridge spreading center. The overlying alkali basalts have trace element compositions of ocean-island-type basalts, and probably formed during subsequent near- or off-axis volcanism, similar to that occurring on young seamounts near the East Pacific Rise (Batiza and Vanko, 1984; Castillo et al., this volume). Dating of Site 801 rocks by the ${ }^{40} \mathrm{Ar} /{ }^{39} \mathrm{Ar}$ technique gives ages of about $165 \mathrm{Ma}$ for the tholeiites and $158 \mathrm{Ma}$ for the alkali basalts, suggesting a time span of approximately $7 \mathrm{~m}$.y. between formation of the MORB tholeiite section and extrusion 
Table 2. Chemical analyses of the hydrothermal desposit and interpillow material from Hole 801C.

\begin{tabular}{|c|c|c|}
\hline $\begin{array}{l}\text { Type: } \\
\text { Core, section: } \\
\text { Interval (cm); } \\
\text { Depth (mbsf): }\end{array}$ & $\begin{array}{c}\text { Hydrothermal } \\
4 \mathrm{R}-1 \\
100-106 \\
522.7\end{array}$ & $\begin{array}{c}\text { Interpillow } \\
12 \mathrm{R}-1 \\
12-14 \\
587.42\end{array}$ \\
\hline $\begin{array}{l}\left(\mathrm{wt}^{2} \%\right) \\
\mathrm{SiO}_{2} \\
\mathrm{TiO}_{2} \\
\mathrm{Al}_{2} \mathrm{O}_{3} \mathrm{~T} \\
\mathrm{Fe}_{2} \mathrm{O}_{3} \mathrm{~T} \\
\mathrm{MnO} \\
\mathrm{MgO} \\
\mathrm{CaO} \\
\mathrm{Na}_{2} \mathrm{O} \\
\mathrm{K}_{2} \mathrm{O} \\
\mathrm{P}_{2} \mathrm{O}_{5}\end{array}$ & $\begin{array}{r}86.50 \\
0.03 \\
0.18 \\
9.97 \\
0.02 \\
0.13 \\
0.08 \\
0.07 \\
0.03 \\
0.03\end{array}$ & $\begin{array}{r}36.00 \\
0.40 \\
2.57 \\
7.67 \\
0.40 \\
4.42 \\
22.80 \\
0.44 \\
1.44 \\
0.02\end{array}$ \\
\hline $\begin{array}{l}\text { LOI } \\
\text { Total }\end{array}$ & $\begin{array}{r}2.23 \\
99.27\end{array}$ & $\begin{array}{r}24.30 \\
100.38\end{array}$ \\
\hline $\begin{array}{l}\mathrm{H}_{2} \mathrm{O}+ \\
\mathrm{CO}_{2} \\
\mathrm{FeO} \\
\mathrm{Fe}^{3+} / \mathrm{Fe}^{\mathrm{T}}\end{array}$ & $\begin{array}{l}1.50 \\
0.01 \\
0.10 \\
0.99\end{array}$ & $\begin{array}{r}2.00 \\
19.10 \\
1.80 \\
0.79\end{array}$ \\
\hline $\begin{array}{l}\text { (ppm) } \\
\mathrm{Ba} \\
\mathrm{Cr} \\
\mathrm{Cu} \\
\mathrm{Nb} \\
\mathrm{Ni} \\
\mathrm{Co} \\
\mathrm{Rb} \\
\mathrm{Sr} \\
\mathrm{Y} \\
\mathrm{Zn} \\
\mathrm{Zr}\end{array}$ & $\begin{array}{r}74 \\
11 \\
<10 \\
17 \\
23 \\
50 \\
<10 \\
<10 \\
<10 \\
28 \\
<10\end{array}$ & $\begin{array}{r}<10 \\
10 \\
42 \\
<10 \\
17 \\
11 \\
50 \\
46 \\
15 \\
29 \\
18\end{array}$ \\
\hline
\end{tabular}

of the alkali basalts (Pringle, this volume). The errors on these ages, particularly for the tholeiites, are sufficient that this time span may be much smaller, less than 2 m.y. (Pringle, this volume).

The saponite-and celadonite-type alteration in the tholeiite section of Hole $801 \mathrm{C}$ is similar to that observed in other altered MORB sections from Deep Sea Drilling Project (DSDP)/ODP cores (Andrews, 1977; Lawrence and Drever, 1981; Alt and Honnorez, 1984; Alt et al., 1986). Saponite-type alteration occurs at low seawater/rock ratios, causing hydration but little other chemical change. The common presence of pyrite indicates generally reducing conditions. The uptake of $\mathrm{K}$ and $\mathrm{Rb}$ and oxidation of $\mathrm{Fe}$ during celadonite-type alteration indicate higher seawater/rock ratios and oxidizing conditions. Temperatures for both alteration types in the tholeiite section were less than $50^{\circ} \mathrm{C}$, and probably less than about $20^{\circ} \mathrm{C}$ as indicated by the whole-rock and calcite oxygen isotopic data (Table 3; FranceLanord et al., this volume). Some constraints can be placed on the absolute timing of alteration of the tholeiites by analogy with other DSDP/ODP cores. Very young rocks $(<1 \mathrm{Ma})$ contain only nontronite-celadonite in and around veins, whereas saponite is also present in slightly older rocks (2-3.5 Ma, Andrews, 1977; Laverne and Vivier, 1981). Although analytical errors and uncertainties in the true age of the crust are often significant, $\mathrm{Rb} / \mathrm{Sr}$ dating of secondary vein minerals in various DSDP/ODP cores indicates that smectite and celadonite alteration are complete within about 10 m.y. (Hart and Staudigel, 1986). These observations suggest that the smectitic (saponite and celadonite) alteration of the MORB tholeiite section at Site 801 may have been complete prior to the extrusion of the overlying alkali basalt section, up to several million years later.

The hydrothermal deposit in Hole 801C probably formed by silicification of an Fe-oxide deposit, similar to those presently forming on seamounts and at mid-ocean ridges (Alt, 1988; Juniper and Fouquet, 1988). Edmond et al. (1979) presented a model for the formation of such Fe-rich deposits. In this model, interaction of seawater with oceanic crust near the top of a magma chamber at a mid-ocean ridge
Table 3. Oxygen and carbon isotopic data for Site 802 basement.

\begin{tabular}{|c|c|c|c|c|}
\hline Sample (cm) & Type of carbonate & $\begin{array}{l}\text { Depth } \\
\text { (mbsf) }\end{array}$ & $\begin{array}{c}\delta^{13} \mathrm{C} \\
(\% \circ \mathrm{PDB})\end{array}$ & $\begin{array}{c}\delta^{18} \mathrm{O} \\
(\% o \text { SMOW })\end{array}$ \\
\hline $\begin{array}{l}\text { 129-801B- } \\
\text { 40R-1, 85-91 } \\
41 \mathrm{R}-1,26-31 \\
41 \mathrm{R}-1,88-94 \\
43 \mathrm{R}-2,21-27 \\
43 \mathrm{R}-3,62-65\end{array}$ & $\begin{array}{l}\text { Whole-rock } \\
\text { Whole-rock } \\
\text { Whole-rock } \\
\text { Whole-rock } \\
\text { Vein }\end{array}$ & $\begin{array}{l}477.75 \\
483.26 \\
483.88 \\
493.78 \\
495.60\end{array}$ & $\begin{array}{l}-3.6 \\
-5.2 \\
-4.5 \\
-0.4 \\
-1.3\end{array}$ & $\begin{array}{l}28.6 \\
29.9 \\
30.2 \\
29.0 \\
26.3\end{array}$ \\
\hline $\begin{array}{l}129-801 \mathrm{C}- \\
2 \mathrm{R}-3,59-64 \\
5 \mathrm{R}-1,103-105 \\
\mathrm{R}-2,87-89 \\
5 \mathrm{R}-3,38-43 \\
5 \mathrm{R}-3,116-121 \\
5 \mathrm{R}-3,125-131 \\
5 \mathrm{R}-3,125-131 \\
6 \mathrm{R}-2,54-58 \\
8 \mathrm{R}-1,65-67 \\
8 \mathrm{R}-2,78-80 \\
9 \mathrm{R}-4,15-20 \\
11 \mathrm{R}-3,58-62 \\
12 \mathrm{R}-1,48-52\end{array}$ & $\begin{array}{l}\text { Vein } \\
\text { Whole-rock } \\
\text { Whole-rock } \\
\text { Whole-rock } \\
\text { Vein } \\
\text { aWhole-rock } \\
\text { bWhole-rock } \\
\text { Vein } \\
\text { Whole-rock } \\
\text { Whole-rock } \\
\text { Vein } \\
\text { Vein } \\
\text { Vein }\end{array}$ & $\begin{array}{l}506.38 \\
532.23 \\
533.33 \\
534.15 \\
534.96 \\
535.02 \\
535.02 \\
542.33 \\
560.15 \\
561.30 \\
567.26 \\
581.38 \\
587.78\end{array}$ & $\begin{array}{r}-4.0 \\
1.9 \\
0.3 \\
0.7 \\
2.0 \\
1.3 \\
1.4 \\
0.3 \\
1.1 \\
0.3 \\
1.1 \\
-1.2 \\
-8.0\end{array}$ & $\begin{array}{l}25.2 \\
27.9 \\
27.3 \\
29.5 \\
27.5 \\
30.4 \\
30.0 \\
30.4 \\
28.2 \\
27.7 \\
30.7 \\
26.7 \\
24.1\end{array}$ \\
\hline Silicates & & & & \\
\hline $\begin{array}{l}\text { 129-801B- } \\
38 \mathrm{R}-1,22-25 \\
43 \mathrm{R}-1,16-20 \\
43 \mathrm{R}-1,22-27\end{array}$ & $\begin{array}{l}\text { Whole-rock } \\
\text { Whole-rock } \\
\text { Whole-rock }\end{array}$ & $\begin{array}{l}466.32 \\
492.36 \\
492.42\end{array}$ & & $\begin{array}{l}18.9 \\
11.2 \\
12.2\end{array}$ \\
\hline $\begin{array}{c}129-801 \mathrm{C}- \\
4 \mathrm{R}-1,100-106 \\
7 \mathrm{R}-3,103-110 \\
10 \mathrm{R}-2,25-31 \\
11 \mathrm{R}-2,131-136 \\
12 \mathrm{R}-3,32-37\end{array}$ & $\begin{array}{l}\text { Quartz } \\
\text { Whole-rock } \\
\text { Whole-rock } \\
\text { Whole-rock } \\
\text { Whole-rock }\end{array}$ & $\begin{array}{l}522.7 \\
554.01 \\
570.75 \\
580.53 \\
590.58\end{array}$ & & $\begin{array}{r}28.0 \\
7.4 \\
6.8 \\
8.0 \\
6.5\end{array}$ \\
\hline
\end{tabular}

results in high temperature (about $350^{\circ} \mathrm{C}$ ), acid hydrothermal fluids depleted in $\mathrm{Mg}$ and enriched in metals, $\mathrm{H}_{2} \mathrm{~S}, \mathrm{Ca}$, alkalis, and silica. These fluids either exit the crust directly to the ocean, forming black smoker-type sulfide deposits at the spreading axis, or mix with cold seawater in the subsurface, precipitating metal sulfide stockwork deposits within the crust. Depending on the $\mathrm{Fe} / \mathrm{H}_{2} \mathrm{~S}$ ratio of the hydrothermal fluid, the resulting mixed and cooled fluid may be $\mathrm{Fe}-$ or $\mathrm{H}_{2} \mathrm{~S}$-rich following subsurface mixing and sulfide precipitation. Such resultant Fe-rich fluids would be depleted in sulfide-forming metals $(\mathrm{Cu}$ and $\mathrm{Zn})$ and would give rise to $\mathrm{Fe}-( \pm \mathrm{Mn})$-rich deposits during oxidation or $\mathrm{pH}$ increase caused by further mixing at the seafloor. The Fe-oxide deposit at Site 801 probably formed from such fluids as they exited the top of the tholeiite section.

Because of kinetic inhibition of quartz nucleation below about $200^{\circ} \mathrm{C}$ (Rimstidt and Barnes, 1980), rapid mixing of hydrothermal fluids with cold seawater can result in silica-rich low-temperature fluids (Janecky and Seyfried, 1984). Given sufficient time, quartz would precipitate from these fluids, and cooling would result in precipitation of amorphous silica or chalcedony (Janecky and Seyfried, 1984; Tivey and Delaney, 1986). Silicification of the hydrothermal $\mathrm{Fe}$-oxide deposit in Hole 801C may have occurred through cooling of such silica-rich distal, low-temperature hydrothermal fluids to form opal or chalcedony, which was later recrystallized to quartz at temperatures of $30^{\circ}-60^{\circ} \mathrm{C}$.

The extensive alteration of the blue-green rocks and their restriction to a 5-m interval immediately beneath the hydrothermal deposit suggest that their alteration is related to the formation of the deposit. The rocks were probably altered through reaction with the distal hydrothermal fluids that formed and silicified the hydrothermal deposit. Slightly elevated temperatures (up to about $50^{\circ} \mathrm{C}$ ) likely increased reaction rates and extent of alteration of the rocks. The $\mathrm{Mg}$-poor, alkali-rich nature of the fluids led to the observed $\mathrm{Mg}$ loss 


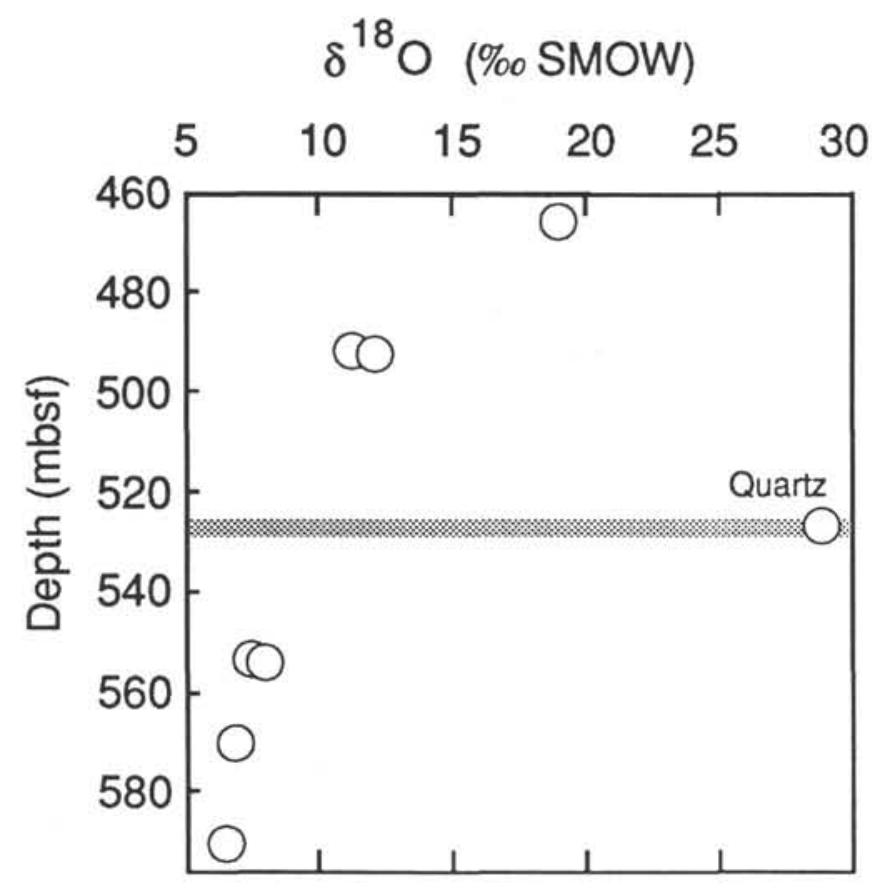

Figure 10. Whole-rock $\delta^{18} \mathrm{O}$ vs. depth for Site 801 basalts. Depth and $\delta^{18} \mathrm{O}$ of hydrothermal deposit also shown.

from the rocks and the formation of abundant K-feldspar. The extensive fracturing of the rocks focused fluid flow and facilitated the extensive alteration of the rocks. Assuming that the $\mathrm{K}_{2} \mathrm{O}$ gained by the rocks $(6 \mathrm{wt} \%)$ was added by uptake of all available $\mathrm{K}$ in seawater gives seawater/rock ratios of about 150 . The altering fluids were likely enriched in $\mathrm{K}$ relative to seawater, but probably not all the $\mathrm{K}$ was taken up from circulating fluids.

The chalcedony present in veins locally throughout the tholeiite section is highly unusual for altered seafloor basalts from DSDP/ODP cores. These veins are restricted to cores beneath the hydrothermal deposit and were probably pathways for Fe- and silica-rich fluids similar to those that formed the hydrothermal deposit. The fractures are now clogged with chalcedony that precipitated during cooling of the system. The spherulitic and vermicular celadonite intergrown with or cemented by chalcedony in some of these veins (e.g., Fig. 5A) may also be hydrothermal in origin, analogous to low-temperature (about $30^{\circ} \mathrm{C}$ ) nontronite-celadonite deposits on the seafloor (Honnorez et al., 1981; Alt, 1988).

The initial intrusion of alkali basalt magma may have provided the heat source and fracturing necessary to drive the hydrothermal system responsible for the hydrothermal deposit in Hole 801C. Subsequent alkali basalt flows erupted from this chamber then covered the hydrothermal deposit. Alteration of the alkali basalts to saponite and celadonite assemblages occurred under conditions generally similar to those during prior alteration of the underlying tholeiites (lower water/rock ratios for saponite, higher ratios for celadonite alteration). Oxygen isotopic data suggest that temperatures in the alkalic section may have been slightly higher than those in the tholeiite section, however. This would have contributed to the breakdown of clinopyroxene and the more extensive alteration of the alkali basalts than the tholeiites. The duration of circulation and alteration may also have been longer in the alkalic section, leading to more extensive alteration of the alkali basalts.

The nearly complete breakdown of plagioclase and clinopyroxene and the extensive alteration of the alkali basalts to $\mathrm{Al}$-saponite assemblages suggests high water/rock ratios. Assuming that the $\mathrm{K}_{2} \mathrm{O}$ increase in these rocks (about $4 \mathrm{wt} \%$ ) is due to the uptake of all available
$\mathrm{K}$ from seawater gives a water/rock ratio of about 100 . Such high water/rock ratios and extensive alteration may have resulted from convection during the same low-temperature hydrothermal circulation responsible for the $\mathrm{Si}-\mathrm{Fe}$ deposit in Hole $801 \mathrm{C}$. An active magma chamber or still-hot crystallized alkali basalt magma chamber could have provided a heat source to drive continued convection, leading to somewhat higher temperatures (up to about $50^{\circ} \mathrm{C}$ ) and higher water/rock ratios during alteration of the alkali basalt section. Convection and further alteration in the tholeiite section would have been restricted if fractures sealed with secondary minerals (e.g., calcite, celadonite, and chalcedony) formed during earlier alteration and prior formation and silicification of the hydrothermal deposit.

Similar Al-rich (beidellite) assemblages in extensively altered rocks from DSDP Hole 417A also formed at high water/rock ratios due to enhanced circulation and relatively "warm" basement temperatures (Alt and Honnorez, 1984). The site is located on a basement hill that remained free of sediment for $10 \mathrm{~m} . \mathrm{y}$., and alteration temperatures were somewhat elevated, at about $30^{\circ}-50^{\circ} \mathrm{C}$. These factors led to the interpretation that the basement hill acted as a "conduit" for the exit of warm basement fluids from the crust, focusing fluid flow and causing the extensive alteration in Hole 417A (Donnelly et al., 1979; Alt and Honnorez, 1984; Bohlke et al., 1984). On a plot of $\delta^{18} \mathrm{O}$ vs. the square root of $\mathrm{K}$ content, the alkali basalts from Site 801 fall along the line defined by samples from Hole 417A (Muehlenbachs, 1980). The rocks from these two sites fall at much higher $\mathrm{K}$ contents than altered rocks from any other DSDP/ODP holes (Muehlenbachs, 1980). The similarity of the data for these two sites on such a diagram may be a coincidence, however. The high $\mathrm{K}$ contents of Hole 417A rocks are attributed to the presence of abundant $\mathrm{K}$-feldspar and celadonite (Bohlke et al., 1984), whereas the alkali basalts from Site 801 start out with higher primary $\mathrm{H}_{2} \mathrm{O}$ and $\mathrm{K}$ contents than normal MORB and would not necessarily be expected to fall along the same alteration trend as MORB (e.g., Fig. 7).

The mineralogical and chemical changes due to alteration of the tholeiites in Hole $801 \mathrm{C}$ are generally similar to those typically seen in much younger MORB sections from DSDP/ODP holes (Andrews, 1977; Bohlke et al., 1984; Alt et al., 1986). The extensive alteration of the blue-green rocks is unusual, but is attributed to localized hydrothermal activity associated with formation of the Si-Fe hydrothermal deposit. The generally greater extent of alteration of the alkali basalt section, particularly the rocks altered to Al-saponite assemblages, is also attributed to slightly higher alteration temperatures and enhanced convection associated with the same circulation system that formed the hydrothermal deposit at Site 801 and postdated alteration of the underlying tholeiites. Besides the general lack of observable aging effects in the rocks, the compositions of pore waters in overlying sediments are not particularly highly reacted (FranceLanord et al., this volume). This is also inconsistent with continued aging reactions in the basement that would likely have affected overlying pore waters (France-Lanord et al., this volume; Gieskes and Lawrence, 1981; Lawrence and Gieskes, 1981). The low-porosity radiolarites near the base of the sediment section (318-443 mbsf) may have prevented diffusive exchange between basement and overlying sediment pore waters, however.

Thus, it appears that there is little difference in alteration of the Jurassic section from Site 801 compared to young ocean crust. One significant difference, however, may be in the abundance of calcite at Site 801 . The younger crust at Hole 504B (5.9 Ma) in the eastern equatorial Pacific has much fewer calcite veins than at Site 801, where multiple generations of calcite have led to abundant calcite veins up to $1.5 \mathrm{~cm}$ wide. The volcanics from Hole $504 \mathrm{~B}$ also have average $\mathrm{CO}_{2}$ contents an order of magnitude lower than that at Site 801 (about $0.1-0.2 \mathrm{wt} \%$ vs. $2.3 \mathrm{wt} \%$, respectively; Alt et al., 1986). Staudigel et al. (1981) noted an increase in $\mathrm{CO}_{2}$ content between younger (3-10 Ma) and older (118 Ma) basement in the Atlantic, and attributed this $\mathrm{CO}_{2}$ increase to calcite formation during progressive aging of the crust. The data for Site 801 fit this interpretation. Another possible 


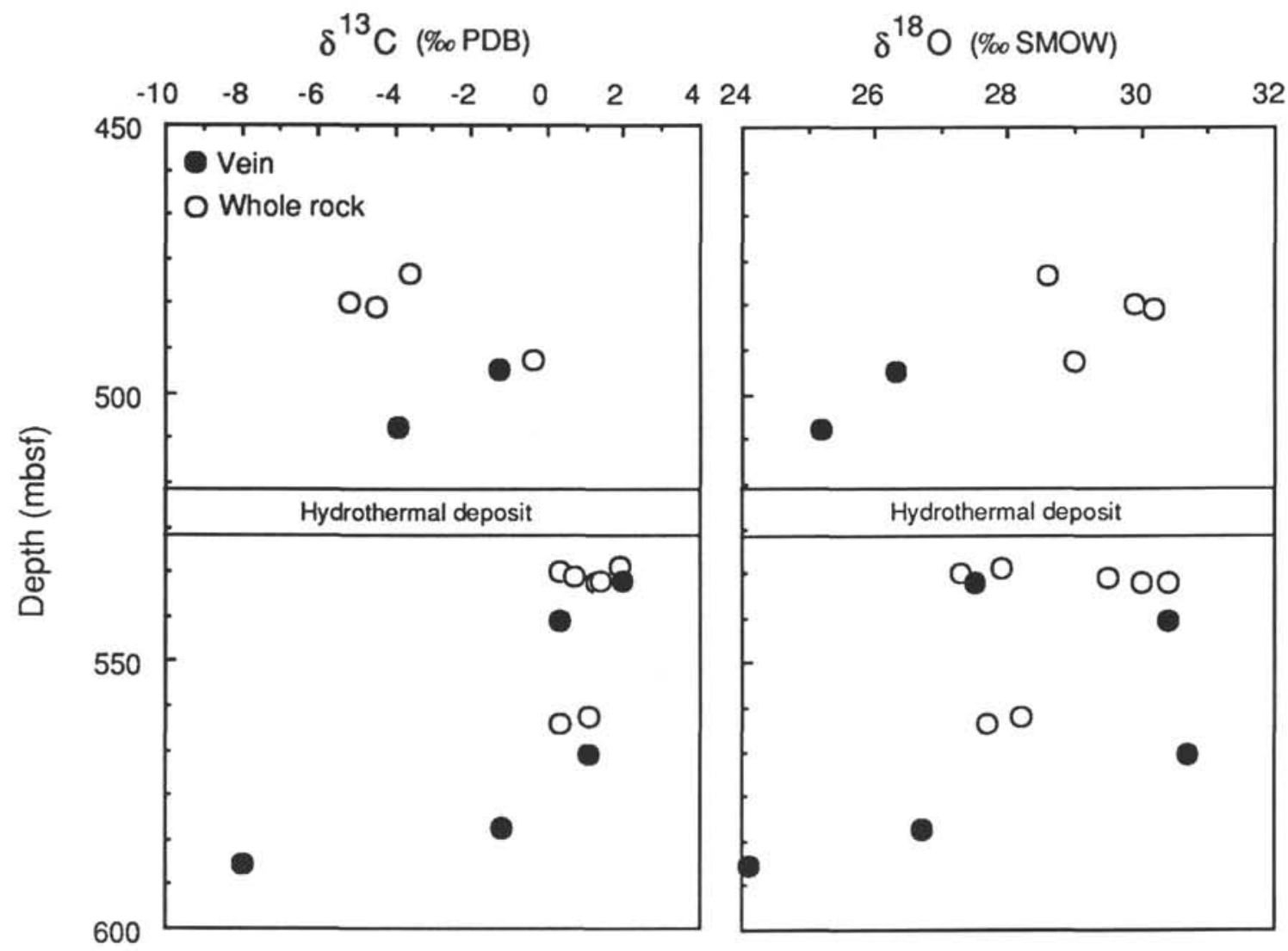

Figure 11. Oxygen and carbon isotopic data for carbonates in Site 801 basement.

aging effect is the high $\delta^{18} \mathrm{O}$ values and extensive alteration of the alkali basalts from Site 801. Lawrence and Gieskes (1981) showed that transport of ${ }^{18} \mathrm{O}$ by diffusion through sediments into the upper oceanic crust during continued low-temperature alteration results in significant ${ }^{18} \mathrm{O}$ uptake by altered crust. Such a process seems unlikely for Site 801 , however, because of the unreacted compositions of pore waters in the sediments immediately overlying basement. Continued flow of seawater along permeable zones in the basement has also been proposed as a means whereby progressive aging reactions can occur between seawater and the crust (Muehlenbachs, 1980; Lawrence and Drever, 1981; Lawrence and Gieskes, 1981). Such reactions could occur where the crust is sealed from communication with overlying seawater by burial beneath sediments, such as at Site 801 .

\section{SUMMARY}

Drilling on Leg 129 penetrated more than $100 \mathrm{~m}$ into $170-\mathrm{Ma}$ basement at Site 801 in the western Pacific. The lower $60 \mathrm{~m}$ of the section consists of tholeiitic basalts formed at a mid-ocean spreading center. A $>3$-m-thick Fe-Si hydrothermal deposit separates the tholeiites from the overlying $60 \mathrm{~m}$ of ocean-island type alkali basalts, which formed near- or off-axis.

Four alteration types have been recognized in Site 801 basement:

1. Saponite-type (Mg-smectite) alteration occurs throughout the tholeiite and alkalic sections. The rocks are generally slightly altered, with olivine replaced by saponite, pyrite, and calcite. The basalts exhibit small increases in $\mathrm{H}_{2} \mathrm{O}, \delta^{18} \mathrm{O}$, and oxidation, reflecting relatively low seawater/rock ratios.

2. Celadonite-type alteration occurs locally in both the tholeiitic and alkalic sections. The rocks are slightly altered with olivine replaced by and vugs filled with celadonite, Fe-oxyhydroxides, saponite, and calcite. Chemical changes include uptake of alkalis and greater oxidation and hydration than saponite-type alteration, reflecting higher seawater/rock ratios for celadonite-type alteration.

3. Al-saponite (Al-Mg smectite) alteration occurs only in the alkali basalts above the hydrothermal deposit. These rocks are moderately to extensively altered to $\mathrm{Al}$-saponite, saponite, calcite, and natrolite. The rocks have gained alkalis and $\mathrm{H}_{2} \mathrm{O}$, exhibit increased oxidation and high $\delta^{18} \mathrm{O}$ values, and have lost $\mathrm{Ca}$ and $\mathrm{Na}$ due to the breakdown of olivine, plagioclase, and clinopyroxene.

4. Blue-green rocks are restricted to a $5-\mathrm{m}$ interval immediately beneath the hydrothermal deposit. These are the most extensively altered rocks, with plagioclase, olivine, and pyroxene variably replaced by K-feldspar, Al-smectite (montmorillonite-beidellite), glauconite, celadonite, and calcite. Chemical changes are also the greatest for these rocks, with large increases in alkalis, oxidation, and hydration, and losses of $\mathrm{Ca}, \mathrm{Na}, \mathrm{Fe}$, and $\mathrm{Mg}$.

Alteration of basement at Site 801 is interpreted in relation to the igneous formation of the crust. The tholeiite section consists of normal MORB formed at a Jurassic mid-ocean spreading center. The saponite- and celadonite-type alteration of these rocks is similar to that in younger altered MORB crust and formed on the flanks of a spreading center at low temperatures $\left(<20^{\circ} \mathrm{C}\right)$.

The hydrothermal deposit consists of spherules, aggregates, and filaments of $\mathrm{Fe}$-oxyhydroxide cemented by quartz. It is interpreted as a low-temperature $\mathrm{Fe}$-oxide deposit, similar to those actively forming on the seafloor at temperatures $<30^{\circ} \mathrm{C}$, which was later silicified at temperatures up to $60^{\circ} \mathrm{C}$. Originally high-temperature $\left(350^{\circ} \mathrm{C}\right)$ metal-rich hydrothermal fluids mixed with seawater deeper in the subsurface to provide the cool, distal $\mathrm{Fe}$ - and Si-rich fluids that formed the hydrothermal deposit. Focusing of low-temperature hydrothermal fluids by fracturing immediately beneath the deposit resulted in the 
extensive alteration and formation of K-feldspar and aluminous phyllosilicates in the blue-green rocks. Following the formation and alteration of the tholeiitic section at a mid-ocean ridge, near- or off-axis intrusion of an alkali basalt magma at depth provided the heat source for hydrothermal fluid reaction and circulation, as well as a magmatic source for the overlying alkali basalts. The latter were altered to saponite and celadonite assemblages, similar to the underlying tholeiites but to a greater extent, reflecting somewhat higher temperatures (up to $50^{\circ} \mathrm{C}$ ) in the alkalic section. Locally higher water/rock ratios resulted in more extensive alteration of plagioclase and the formation of aluminous phyllosilicates in Al-saponite-type alteration in the alkalic section. The generally greater extent of alteration of the alkalic section relative to the tholeiitic section is attributed to sealing of the tholeiites during prior low-temperature alteration near the spreading axis and by precipitation of celadonite and chalcedony during the formation of the hydrothermal deposit, whereas circulation of seawater and alteration of the alkali basalts continued in the later stages of the low-temperature system that produced the hydrothermal deposit.

Alteration of the Site 801 basement is generally similar to that observed in young Pacific crust (6 Ma, Hole 504B), with the exceptions of greater amounts of calcite and higher $\delta^{18} \mathrm{O}$ values in the alkalic section at Site 801 . The more abundant calcite is attributed to precipitation of calcite during progressive aging of the crust during its long history away from the spreading center. The higher $\delta^{18} \mathrm{O}$ values of the alkalic section are interpreted to be due to higher alteration temperatures related to slightly higher temperature circulation in this section following formation of the hydrothermal deposit, but may have been caused in part by a longer duration of seawater circulation in the alkalic section.

\section{ACKNOWLEDGMENTS}

J. A.'s contribution was supported by NSF OCE-901836. James R. Lawrence and Karlis Muehlenbachs provided helpful reviews of an earlier version of the manuscript.

\section{REFERENCES}

Alt, J. C., 1988. Hydrothermal oxide and nontronite deposits on seamounts in the eastern Pacific. Mar. Geol., 81:227-239.

Alt, J. C., and Honnorez, J., 1984. Alteration of the upper oceanic crust, DSDP Site 417: mineralogy and processes. Contrib. Mineral. Petrol., 87:149-169.

Alt, J. C., Honnorez, J., Laverne, C., and Emmermann, R., 1986. Hydrothermal alteration of a $1 \mathrm{~km}$ section through the upper oceanic crust, DSDP Hole 504B: mineralogy, chemistry, and evolution of seawater-basalt interactions. J. Geophys. Res., 91:10309-10335.

Alt, J. C., Lonsdale, P., Haymon, R., and Muehlenbachs, K., 1987. Hydrothermal sulfide and oxide deposits on seamounts near $21^{\circ} \mathrm{N}$, East Pacific Rise. Geol. Soc. Am. Bull., 98:157-168.

Andrews, A. J., 1977. Low temperature fluid alteration of oceanic Layer 2 basalts. Can. J. Earth Sci., 14:911-926.

Batiza, R., and Vanko, D., 1984. Petrology of young Pacific seamounts. $J$. Geophys. Res., 89:11235-11260.

Bohlke, J. K., Alt, J. C., and Muehlenbachs, K., 1984. Oxygen isotope-water relations in altered deep-sea basalts: low-temperature mineralogical controls. Can. J. Earth Sci., 21:67-77.

Buchanan, R. E., and Gibbons, N. E., 1974. Bergey's Manual of Determinitive Bacteriology (8th ed.): Baltimore (Williams and Wilkins).

Carothers, W. W., Adami, L. H., and Rosenbauer, R. J., 1988. Experimental oxygen isotope fractionation between siderite-water and phosphoric acid liberated $\mathrm{CO}_{2}$-siderite. Geochim. Cosmochim. Acta, 52:2445-2450.

Clayton, R. N., and Mayeda, T. K., 1963. The use of bromine pentafluoride in the extraction of oxygen from oxids and silicates for isotopic analysis. Geochim. Cosmochim. Acta, 27:43-52.
Craig, H., 1961. Standard for reporting concentrations of deuterium and oxygen-18 in natural waters. Science, 133:1833-1834.

Donnelly, T. W., Thompson, G., and Salisbury, M., 1979. The chemistry of altered basalts at Site 417A, DSDP Leg 51. In Donnelly, T., Francheteau, J., Bryan, W., Robinson, P., Flower, M., Salisbury, M., et al., Init. Repts. DSDP, 51, 52, 53 (Pt. 2): Washington (U.S. Govt. Printing Office), 1319-1330.

Edmond, J. M., Measures, C., Magnum, B., Grant, B., Sclater, F. R., Collier, R., Hudson, A., Gordon, L. I., and Corliss, J. B., 1979. On the formation of metal-rich deposits at ridge crests. Earth Planet. Sci. Lett., 46:19-30.

Gieskes, J. M., and Lawrence, J. R., 1981. Alteration of volcanic matter in deep-sea sediments: evidence from the chemical composition of interstitial waters from deep-sea drilling cores. Geochim. Cosmochim. Acta, 45:1687-1703.

Hart, S. R., and Staudigel, H., 1986. Ocean crust vein mineral deposition: $\mathrm{Rb} / \mathrm{Sr}$ ages, U-Th-Pb geochemistry, and duration of circulation at DSDP Sites 261, 462 and 516. Geochim. Cosmochim. Acta, 50:2751-2761.

Honnorez, J., Von Herzen, R. P., Barrett, T. J., Becker, K., Bender, M. L., Borella, P., Hubberten, H., Jones, S., Karato, S., Laverne, C., Levi, S., Migdisov, A., Moorby, S., and Schrader, E., 1981. Hydrothermal mounds and young oceanic crust of the Galapagos: preliminary DSDP results. Geol. Soc. Am. Bull., 92:457-472.

Janecky, D. R., and Seyfried, W. E., 1984. Formation of massive sulfide deposits on oceanic ridge crests: incremental reaction models for mixing between hydrothermal solutions and seawater. Geochim. Cosmochim. Acta, 48:2723-2738.

Juniper, S. K., and Fouquet, Y., 1988. Filamentous iron-silica deposits from modern and ancient hydrothermal sites. Can. Mineral., 26:859-870.

Kyser, T. K., 1986. Stable isotope variations in the mantle. In Valley, J. W., Taylor, H. P., and O'Neil, J. R. (Eds.), Stable Isotopes in High Temperature Geological Processes. Mineral. Soc. Am., 141-164.

Lancelot, Y., Larson, R., et al., 1990. Proc. ODP, Init. Repts., 129: College Station, TX (Ocean Drilling Program).

Lawrence, J. R., 1991. Stable isotopic composition of pore waters and calcite veins. In Weissel, J., Peirce, J., Taylor, E., and Alt, J., et al., Proc. ODP, Sci. Results, 121: College Station, TX (Ocean Drilling Program), 1-6.

Lawrence, J. R., and Drever, J. I., 1981. Evidence for cold water circulation at DSDP Site 395: isotopes and chemistry of alteration products. $J$. Geophys. Res., 86:5125-5133.

Lawrence, J. R., and Gieskes, J. M., 1981. Constraints on water transport and alteration in the oceanic crust from the isotopic composition of pore water. J. Geophys. Res., 86:7924-7934.

Matsuhisa, Y., Goldsmith, J. R., and Clayton, R. N., 1979. Oxygen isotope fractionation in the system quartz-albite-anorthite-water. Geochim. Cosmochim. Acta, 43:1131-1140.

Muehlenbachs, K., 1980. The alteration and aging of the basaltic layer of the sea floor: oxygen isotopic evidence from DSDP/IPOD legs 54, 52, 53. In Donnelly, T., Francheteau, J., Bryan, W., Robinson, P., Flower, M., Salisbury, M., et al., Init. Repts. DSDP, 51, 52, 53 (Pt. 2), Washington (U.S. Govt. Printing Office), 1159-1168.

Muehlenbachs, K., and Clayton, R. N., 1972. Oxygen isotope studies of fresh and weathered submarine basalts. Can. J. Earth Sci., 9:172-184.

O'Neil, J. R., Clayton, R. N., and Mayeda, T. K., 1969. Oxygen isotope fractionation in divalent metal carbonates. J. Chem. Phys., 51:5547-5558.

Petersen, N., Eisenach, P., and Bleil, U., 1979. Low temperature alteration of the magnetic minerals in ocean floor basalts. In Talwani, M., Harrison, C.G.A., and Hayes, D. E. (Eds.), Deep Drilling Results in the Atlantic Ocean: Ocean crust. Am. Geophys. Union, 169-209

Rimstidt, J. D., and Barnes, H. L., 1980. The kinetics of silica-water reactions. Geochim. Cosmochim. Acta, 44:1683-1699.

Staudigel, H., Hart, S. R., and Richardson, S. H., 1981. Alteration of the oceanic crust: processes and timing. Earth Planet. Sci. Lett., 52:311-327.

Tivey, M. K., and Delaney, J. R., 1986. Growth of large sulfide structures on the Endeavor segment of the Juan de Fuca Ridge. Earth Planet. Sci. Lett., 77:303-317.

Date of initial receipt: 4 June 1991

Date of acceptance: 8 October 1991

Ms 129B-132 